\title{
LATE CRETACEOUS STRATIGRAPHY OF THE SOUTHEASTERN CHACO - PARANÁ BASIN (“NORTE BASIN” - URUGUAY): THE MAASTRICHTIAN AGE OF THE CALCRETIZATION PROCESS
}

\author{
ESTRATIGRAFIA DO CRETÁCEO SUPERIOR DAS BACIAS DO SUDESTE DO CHACO E DO \\ PARANÁ ("BACIA DO NORTE” - URUGUAI): IDADE MAASTRICHITIANA DO PROCESSO DE \\ CALCRETIZAÇÃO
}

\author{
Gerardo VEROSLAVSKY ${ }^{1}$; Natalie AUBET ${ }^{2}$; Sergio A. MARTÍNEZ ${ }^{1}$; Larry M. \\ HEAMAN $^{3}$; Fernanda CABRERA ${ }^{1}$; Valeria MESA ${ }^{1}$ \\ ${ }^{1}$ Universidad de la República de Uruguay. Instituto de Ciencias Geológicas. Iguá 4225 -Montevideo, Uruguay \\ Emails: gerardo@fcien.edu.uy; smart@fcien.edu.uy; fcabrera@fcien.edu.uy; vmesa@fcien.edu.uy \\ ${ }^{2}$ Universidad Tecnologica del Uruguay. Departamento de Ciencias Ambientales, Francisco Maciel s/n - Durazno, Uruguay \\ Email: natalie.aubet@utec.edu.uy \\ ${ }^{3}$ University of Alberta. Faculty of Earth Sciences. 116 St and 85 Ave., Edmonton, Alberta, Canada \\ Email:Iheaman@ualberta.ca

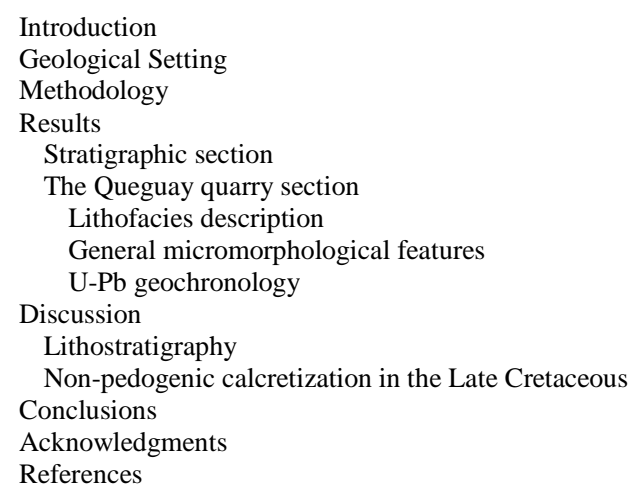

ABSTRACT - In the last 40 years, successive revisions have been introduced to the lithostratigraphy of the Late Cretaceous of the Norte Basin, whose record is formed by predominantly siliciclastic continental fossiliferous sedimentary rocks. A factor that contributed to the terminology proliferation was the misplaced importance attributed to the epigenetic processes and products (calcretes and ferricretes, occasionally fossiliferous) affecting those siliciclastic rocks. Based on field work and lithological logs from a number of key areas, the validity of the original stratigraphic column showing, from base to top, the Guichón, Mercedes, Asencio and Queguay formations is supported. For those particular units, the lithostratigraphic scope given by the original definitions is correct and, with minimum adjustments, they should be restored for their practical usefulness as geological mapping units. An evolutionary scheme for the Late Cretaceous of the Norte Basin is herein presented, with the aim of contributing to a greater understanding of the succession of sedimentary and epigenetic processes. A Maastrichtian age is proposed for the carbonatic cementation and/or substitution that affected the Mercedes and Asencio formations, thus originating the Queguay Formation, based on absolute age of the calcite cement ( $72 \mathrm{Ma}$; U-Pb), paleontological data, and the correlation established with similar events recorded in the Marília Formation in the Bauru Basin (Brazil).

Keywords: Late Cretaceous, lithostratigraphy, calcretes, Norte Basin.

RESUMO - Nos últimos 40 anos foram apresentadas sucessivas revisões da litoestratigrafia do Cretáceo Superior da Bacia do Norte, Uruguai, cujo registro é constituído predominantemente por rochas sedimentares continentais fossilíferas. Um fator que contribuiu para a proliferação de denominações litoestratigráficas foi a equivocada importância atribuída aos processos e produtos epigenéticos (calcretes e ferricretes, ocasionalmente fossilíferos) que afetaram as rochas siliciclásticas. Com base em trabalhos de campo e perfis litológicos de áreas-chave, confirmamos a validade da coluna estratigráfica originalmente proposta, da base para o topo composta pelas formações Guichón, Mercedes, Asencio and Queguay. Estas formações, com pequenos ajustes em relação à definição original, são úteis como unidades para fins de mapeamento. Um esquema evolutivo para o Cretáceo superior da Bacia do Norte é proposto com o objetivo de contribuir para o entendimento da sucessão de eventos sedimentares e epigenéticos. Com base na datação absoluta do cimento calcítico ( $72 \mathrm{Ma}$; U-Pb), em dados paleontológicos e na correlação com eventos similares registrados na Formação Marília da Bacia Bauru no Brasil, é atribuída idade maastrichtiana para a cimentação e/ou substituição carbonática que afetou as formações Mercedes e Asencio, assim originando a Formação Queguay.

Palavras-chave: Cretáceo Superior, Litoestratigrafia, calcretes, Bacia Norte

\section{INTRODUCTION}

The opening of the Atlantic Ocean resulted in tectonic processes developing new basins at the the splitting of Western Gondwana, with eastern margin of the South American Platform 
(Almeida et al., 2000; Schobbenhaus \& Brito Neves, 2003) and the sedimentation characteristics changing to a great extent. Particularly during the Late Cretaceous, the new tectonic and depositional scenarios favored the accumulation of continental sediments unconformably overlying the Early Cretaceous basaltic areas formed within the old domains of the Paleozoic Paraná and Chaco-Paraná basins (Figure 1).

This situation promoted the development of clastic and fossiliferous alluvial, fluvial, lacustrine, and aeolian depositional systems (Fernandes \& Coimbra, 1996), greatly influenced by a regional west-southwest trending flow that transported sediments down paleoslope from the Paleo Paraná-Plata systems to the Salado and Punta del Este basins (Potter,
1997). The most notorious characteristics of these basins are the total replacement of the Late Cretaceous host rocks by carbonate, the local but intense silica diagenesis, and the existence of pedogenetic processes, resulting in various types of calcrete, ferricrete and silcrete deposits.

The origin, source, age, and extent of these diagenetic and pedogenetic processes, along with their lithostratigraphic arrangement and their relationship with the fossil content of the host rocks, have been under much scrutiny (e.g. in Uruguay: Frenguelli, 1930; Walther, 1930; Lambert. 1939, 1940; Goso \& Bossi, 1966; Sprechmann et al., 1981; in Brazil: Setzer, 1948; Almeida \& Barbosa, 1953; Suguio \& Barcelos 1983; in Argentina: Herbst, 1980; Tófalo, 1986).

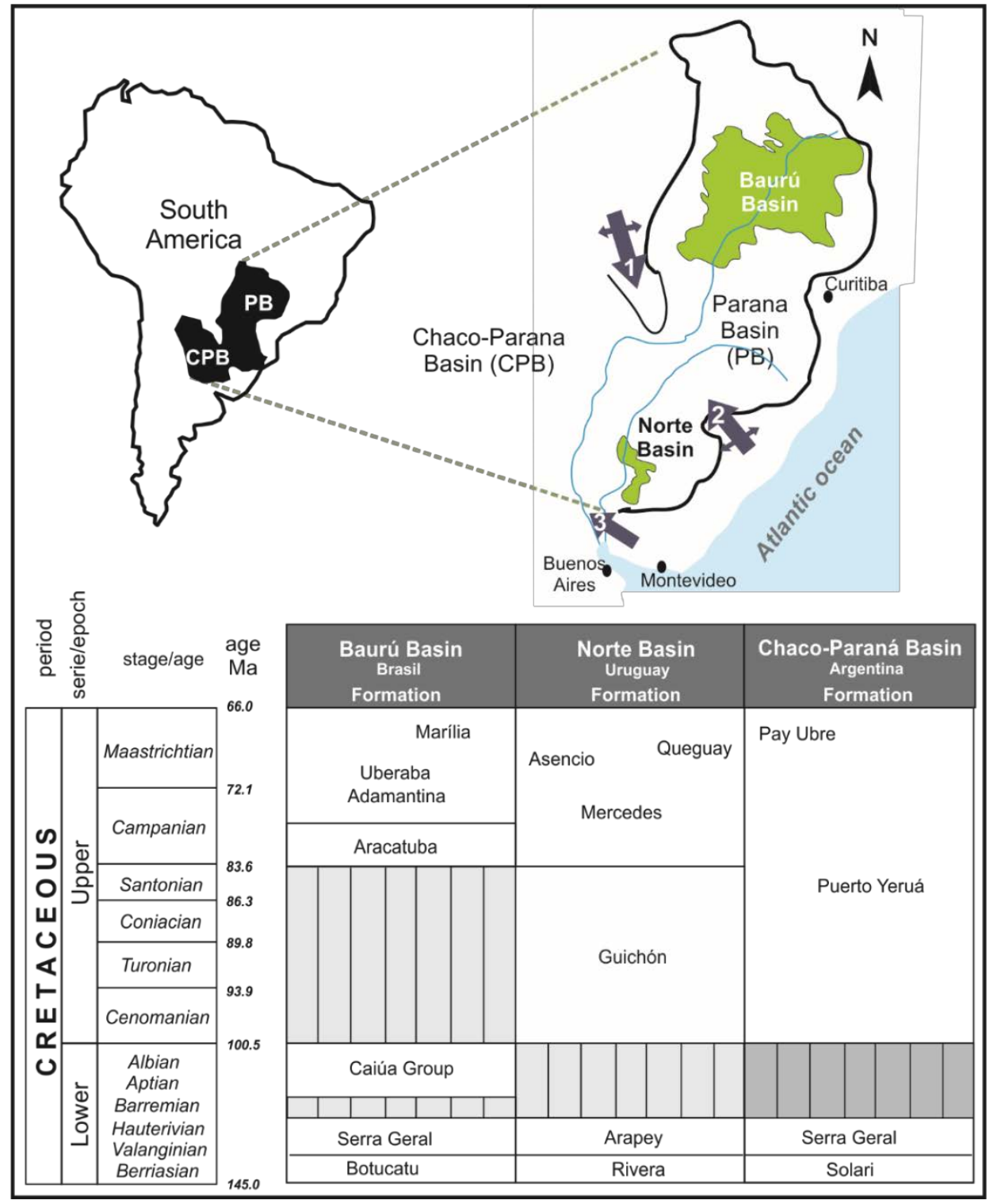

Figure 1 - Schematic distribution of the Late Cretaceous sedimentary record in the Paraná and Chaco-Paraná, and lithostratigraphic correlation at regional scale (source: Fúlfaro et al., 1997; Chebli et al., 1989; Goso \& Perea, 2003; Tófalo et al., 2001). 
In the Uruguayan portion of the Paraná Basin (known as "Norte Basin"), Late Cretaceous sedimentary rocks are located in its western region (Figure 2) and special attention has been paid to the origin and preservation of carbonate sedimentary rocks and to the biostratigraphic and paleoecologic significance of the fossil record. Consequently, a considerable number of scientific

contributions

discuss

the pedogenetic/diagenetic schemes concerning the formation of calcretes in the Mercedes, Asencio and Queguay formations (Tófalo, 1986; Veroslavsky \& Martínez, 1996; Veroslavsky et al., 1997; Tófalo et al., 2001; Tófalo \& Morras, 2009; Tófalo \& Pazos, 2010; Alonso-Zarza et al., 2012; Martínez et al., 2015; Cabrera et al., 2018).

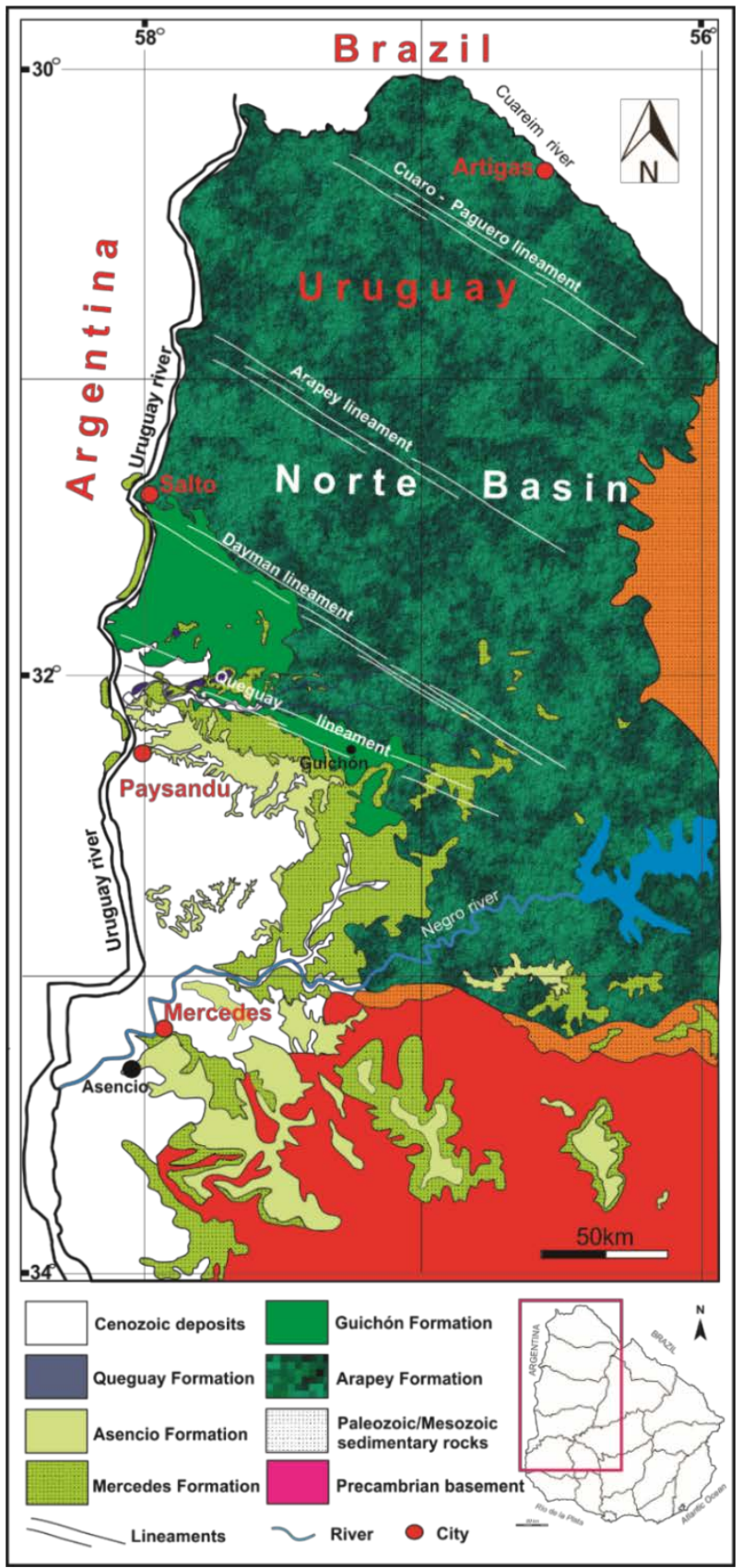

Figure 2 - Simplified geological map showing the distribution of the Late Cretaceous sedimentary rocks in the Norte Basin (modified from Preciozzi et al., 1985; Veroslavsky \& de Santa Ana, 2004).

Based on extensive field work in key areas, fundamental contributions on paleontological aspects of the Queguay Formation, and the results of experimental radiometric (U-Pb) dating of early diagenetic carbonate phases, in this paper we review the lithostratigraphy of the Late Cretaceous in the Norte Basin of Uruguay, within the framework of the paleogeographic context given by the Bauru Basin and the Argentinean Mesopotamia.

Furthermore, we discuss the epigenetic mechanisms that altered the Late Cretaceous sediments and the biostratigraphic significance of their fossil content. 


\section{GEOLOGICAL SETTING}

The Late Cretaceous record of the Paraná and Chaco-Paraná basins comprises continental sediments up to $500 \mathrm{~m}$ thick in Brazil (Bauru Basin) and 250m thick in Uruguay (Norte Basin). In both basins, the presence of different types of paleosols and weathering profiles shows the evolution of the sedimentary systems under arid-to semi-arid conditions, a variable paleotopography, and fluctuating local and regional moisture regimes.

The Brazilian continental Bauru Basin is located in the southeast and southern region of the country (Figure 1), covering an area of 350,000 $\mathrm{km}^{2}$ (Fúlfaro \& Perinotto, 1996), reaching Northeastern Paraguay (Fúlfaro 1996). It is mostly filled with a clastic continental succession (Menegazzo et al., 2016). The Bauru Basin contains the Caiuá and Bauru groups (Fernandes \& Coimbra 1996, 2000; Fúlfaro \& Perinotto, 1996; Paula \& Silva et al., 2005; Fernandes, 2010; Batezelli, 2010, 2015). The Marília Formation is of particular interest to this study, as it represents the uppermost sedimentary record of the Bauru Group (Figure 1).

According to Menegazzo et al. (2016), it consists of fining-upward cycles including matrixsupported conglomerates with intra- and extraformational clasts, fine to very coarse sandstones (massive, cross-stratified, or ripple crosslaminated), and rare mudstones. Calcrete structures are quite common (laminar, prismatic, or massive horizons), with abundant carbonate nodules (vertical elongated, branched, or with irregular shape), horizontal cracks, and rhizoconcretions. The Marília Formation is divided into three members: Ponte Alta, Serra da Galga, and Echaporã (Barcelos, 1984; Barcelos \& Suguio 1987).

The Ponte Alta and Echaporã members have calcretes and sandstones with abundant carbonate cement. Furthermore, commercial limestone deposits - calcretes - occur in the Ponta Alta Member (Fúlfaro et al., 1997). As for its paleontological data, the most noticeable aspect is the rich-fossil reptilian assemblage of the Marília Formation, which was dated as Maastrichtian by means of vertebrate fossils (Santucci \& Bertini, 2001) as well as other fossils and paleomagnetic data (Dal' Bó \& Ladeira, 2006; Da Silva et al., 2017).

In the Argentinean Mesopotamia, there are calcretes in the Cretaceous siliciclastic sandstones and conglomerate successions exposed along the right margin of the Uruguay River (Tófalo \& Pazos, 2002). These rocks correspond to the Puerto Yeruá Formation (De Alba \& Serra, 1959), and their facies and calcrete types were first described and interpreted by Tófalo (1986).

Northwards, the "calcareous sedimentites" from the Corrientes Province were described by Herbst (1980) as two lithostratigraphic units: part of them were included in the Pay Ubre Formation (Late Cretaceous, correlated with the Uruguayan Mercedes Formation), and the remainder, in the Fray Bentos Formation (Oligocene, correlated with the homonymous Uruguayan unit).

In Uruguay, the sedimentary infill of the Norte Basin (Figure 2) is divided into four lithostratigraphic units: Guichón, Mercedes, Asencio, and Queguay formations (Figure 3). The Guichón Formation (Bossi, 1966 = Guichón sandstones Lambert, 1940) consists of around $200 \mathrm{~m}$ of medium-to-fine grained orthoconglomerates that grade down into coarse to medium grained sandstones and pelites, deposited in a proximal braided fluvial system (Goso \& Perea, 2003).

Sandstones are locally bioturbated, and generally show massive and/or cross-bedding structures. Mudstones are scarce, but when present they are thin and massive, depicting ephemeral lakes and short flooding episodes. At the top of the Guichón Formation, there are aeolian deposits (Riccardi, 1998; Tófalo \& Pazos, 2010). This unit unconformably overlies Early Cretaceous basalts, with its deposition controlled by pre-existing Precambrian basement NE-SW structures.

The Mercedes Formation (Bossi, $1966=$ Mercedes sandstones, Serra, 1945) mostly and unconformably overlies the Guichón Formation and at times locally Cretaceous basalts, and it is covered by the Asencio Formation (Maastrichtian). It consists of several finingupward fluvial cycles of matrix- and clastsupported conglomerates, including intra- and extra-formational clasts, conglomeratic sandstones, coarse to fine-grained sandstones with massive and cross-stratification, and rare mudstones (Tófalo \& Pazos, 2001). 

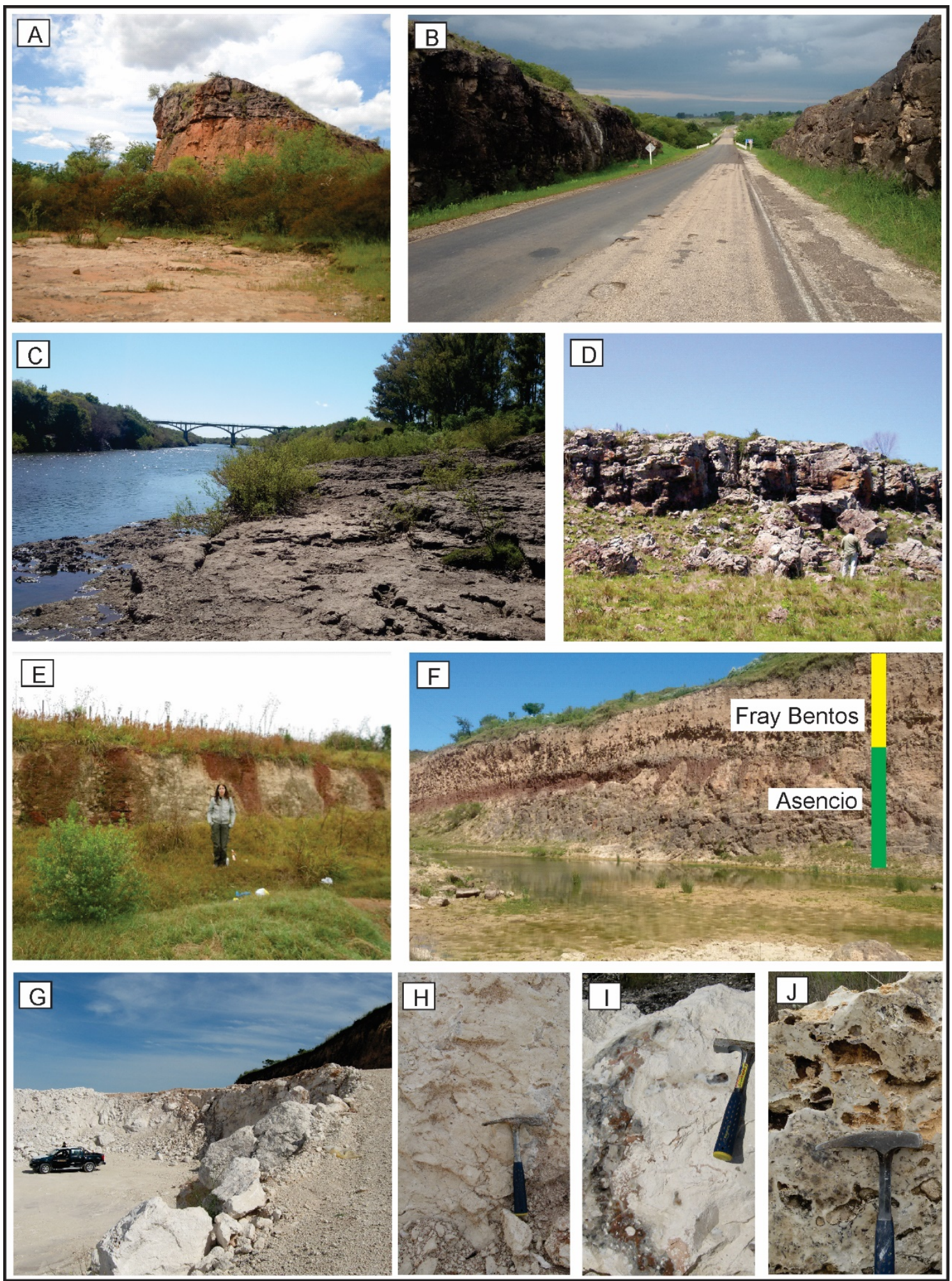

Figure 3 - Lithostratigraphic units of the Late Cretaceous record in the Norte Basin. From base to top: A) Guichón - Mercedes Formation contact at the "Meseta de Artigas" site; B) Outcrop near Soto creek (route 26). Basal Mercedes Formation: fluvial channel and bar sequences with interbedded paleosols; C) Mercedes sandstones with abundant carbonatic cement at the Queguay river site (route 3); D) Mercedes fluvial sandstones near the village of Guichón; E) Asencio fine whitish/off-white sandstones with the ferriferous columns in the Asencio Formation type area (route 12 / Dacá creek); F) Discontinuous ferruginous crust developing along the contact Asencio - Fray Bentos Formation (UTM X = 398479, Y = 6306094; G) General view of non-pedogenic groundwater calcretes in a limestone mining front (Queguay quarry); H) Relicts of the host rocks (coarse-to-medium sandstones) preserved during the calcretization processes; I) and J) Close-up view of different types of silcretized calcretes.

A maximum thickness of around $100 \mathrm{~m}$ of sandstones was identified in subsurface, and interpreted as stacked fluvial channels generated in braided to distal-braided low-sinuosity systems (Chebli et al., 1989; Goso \& Perea, 2003). Beds with carbonate cement in siliciclastic sandstones, 
intercalated with limestone levels, sometimes highly affected by very early diagenetic silicification, are common. The fossil content includes freshwater and terrestrial gastropods, Neosauropoda eggshells, rizoliths, and ichnofossils (Table 1) (see Cabrera et al., 2018 and references therein).

The original description of the Asencio Formation (Bossi, 1966 = Asencio sandstones, Caorsi \& Goñi, 1958 = sandstones with dinosaurs, Serra, 1945) mentioned around $40 \mathrm{~m}$ of "very homogeneous pale pink to white fine-grained sandstones with variable matrix (clay) content and carbonate cement" overlying the Mercedes Formation and the Precambrian granites. The Asencio Formation represents highly sinuous lowenergy meandering systems, including thin heterolithic units in the uppermost part, interpreted as splay deposits recording reworking and accumulation of sediments.

At the top of the unit, weathering zones and paleosols (e.g., ferricretes, laterites) were developed, overprinting - and, in many cases, masking - the original sedimentary features. Ferruginous sandstones and all the Fe-rich paleosols and Feduricrusts were grouped by Caorsi \& Goñi (1958) into the "del Palacio facies", lithologies later included by Bossi (1966) in the del Palacio Member (= del Palacio sandstones, Walther, 1919) of the Asencio Formation. Bossi (1966) stated that due to its scarce development, little thickness, and discontinuous character, it is not possible to map the del Palacio Member. This author also defined the Yapeyú Member, thus grouping together the remainder of the fine-white and homogenous sandstones of the Asencio Formation. Furthermore, the Algorta Member was established by Preciozzi et al. (1985) to include the highly carbonate cemented sandstones of the Asencio Formation, and its silicified-fossiliferous limestone levels.

Other descriptions - different from the original definition - of the Asencio Formation included duricrusts, laterites, ferricretes, or paleosols overprinting a fluvial sandstone host (Morrás et al., 2010). Goso (1999) defined a single unit which he called the Mercedes-Asencio Formation and, subsequently, Goso \& Perea (2003) proposed to abandon the Asencio denomination, considering the Mercedes Formation as integrated by the del Chileno, Yapeyú and del Palacio members. Ford \& Gancio (1989a, 1989b) proposed to restrict the name of Asencio
Formation to the Yapeyú Member, defined by Bossi (1966), and provisionally defined the Palmitas Formation, a new stratigraphic unit of intense reddish color, composed of conglomerates of purported fluvial origin, developed from the erosion of ferralitic soils that contain fossil insect nests, and tentatively assigned it to the early Cenozoic.

Later on, Pazos et al. (1998) limited the name of Asencio Formation to the del Palacio Member, as they found a regional unconformity which they named as the Yapeyú paleosurface. More recently, Alonzo Zarza et al. (2011) modified the original definition of the Asencio Formation, including under this name only the ferruginous levels of the Palacio Member and some putative Paleogene continental deposits. Regarding the fossil content, Titanosaurs were mentioned by several authors (see Table I) as found in the uppermost levels of the Asencio Formation, where weathering profiles occur (Huene, 1929; Walther, 1933; Mones, 1980, Perea \& Martínez, 1985).

The Queguay Formation (del Queguay Limestones, Lambert, 1940) was formally established by Goso \& Bossi (1966) to include the limestones, sandstones and conglomerate sandstones with carbonate cements that occur along the valley of the Queguay River, reaching a maximum thickness of 25m (Figure 2).

Sometimes the carbonates of the host rock are replaced by silica. When the replacement is significant, it generates cherts and opaline that can be found in outcrops and subsurface levels as lenticular beds or irregular bodies. Initially considered as lacustrine deposits (Lambert, 1940; Serra, 1945; Bossi, 1966; Sprechmann et al., 1981), the origin of the Queguay limestones has been a matter of debate during the past decades. Based on the similarity of the Queguay limestones with those of the Puerto Yeruá Formation, Tófalo (1986) suggested that they were formed by the rise to the near surface of lateral and capillary waters from the saturated level.

According to Veroslavsky et al. (1997), Queguay limestones were originated during the Paleogene as the result of groundwater discharge from a large regional flow system controlled by pre-existing structures (the Queguay Lineament, see Figure 2), that raised the phreatic level and favored degassing, evaporation, and evapotranspiration processes. Tófalo \& Pazos (2010) described two carbonate rocks in the Queguay Formation: calcretes and palustrine carbonates. 
Table 1- Fossil record of the Late Cretaceous in the Norte Basin. Huene, 1929 (1), 1934 (2); Frenguelli, 1930 (3); Walther, 1930 (4); Rusconi, 1933 (5); Roselli, 1939 (6), 1987 (7); Parodiz, 1969 (8); Mones, 1980 (9); Morton \& Herbst, 1993(10); Mones, 1997 (11); Martínez et al., 2001 (12); Genise \& Verde, 2000 (13); Perea et al., 2009 (14); Alonso-Zarza et al., 2011 (15); Soto et al., 2011a (16), 2011b (17); Verde, 2012 (18); Cabrera \& Martínez, 2012 (19), 2017(20); Cabrera et al., 2016 (21), 2018 (22).

\begin{tabular}{|c|c|c|c|}
\hline Formation & $\begin{array}{l}\text { Stratigraphic } \\
\text { position }\end{array}$ & Fossil & Localities \\
\hline Queguay & $\begin{array}{l}\text { Several } \\
\text { levels of the unit } \\
\text {-calcretes, } \\
\text { calcretes/silcretes, } \\
\text { sandstones with } \\
\text { abundant calcite } \\
\text { cement }\end{array}$ & $\begin{array}{l}\text { Biomphalaria walteri }(4,8) \\
\text { Biomphalaria reversa(21) } \\
\text { Succineidae indet.(10) } \\
\text { Pupoides (Ischnopupoides) gnocco(20) } \\
\text { Bulimulus klappenbachi }(3,8) \\
\text { Bahiensis priscus }(19) \\
\text { Eoborus charruanus }(15) \\
\text { Ostracoda (12) } \\
\text { Neosauropoda eggshells Sphaerovum erbeni (9) } \\
\text { Characean gyrogonites }(12) \\
\text { Celtis santosi endocarps }(22) \\
\text { Wood (15) } \\
\text { Rhizoliths }(12) \\
\text { Celliforma isp. }(12) \\
\text { Fictovichnus isp. }(18,15)\end{array}$ & $\begin{array}{l}\text { quarry in Quebracho Ville, PayD* } \\
\text { quarry in Quebracho Ville, PayD* } \\
\text { quarry in Quebracho Ville, PayD* } \\
\text { quarry in Quebracho Ville, PayD* } \\
\text { quarry in Quebracho Ville, PayD* } \\
\text { quarry in Quebracho Ville, PayD* } \\
\text { quarry in Quebracho Ville, PayD* } \\
\text { quarry in Quebracho Ville, PayD* } \\
\text { Near theintersection of Route } 90 \text { with Route 25, PayD* } \\
\text { quarry in Quebracho Ville, PayD** } \\
\text { quarry in Quebracho Ville, PayD* } \\
\text { Near the intersection of Route } 90 \text { with Route 25, PayD* } \\
\text { quarry in Quebracho Ville, PayD* } \\
\text { quarry in Quebracho Ville, PayD* } \\
\text { All Queguay }\end{array}$ \\
\hline & $\begin{array}{l}\text { Top of the } \\
\quad \text { unit } \\
\text { (ferruginousos } \\
\text { sandstones and } \\
\text { paleosols) } \\
\text { Several levels of } \\
\text { the unit }\end{array}$ & $\begin{array}{l}\text { Uruguay isp. }(6,18) \\
\text { Teisseirei isp. }(6,18) \\
\text { Corimbatichnus isp. }(13,18) \\
\text { Elipsoideichnus isp. }(7,18) \\
\text { Palmiraichnus isp. }(7,18) \\
\text { Rebuffoichnus isp. }(7,18) \\
\text { Coprinisphaera isp. }(6,18) \\
\text { Monesichnus isp. }(7,18)\end{array}$ & $\begin{array}{l}\text { FloD, ColD, SorD and DurD } \\
\text { ColD, SorD and DurD } \\
\text { ColD, SorD and DurD } \\
\text { ColD and SorD } \\
\text { ColD, SorD and DurD } \\
\text { ColD and SorD } \\
\text { FloD, ColD, SorD and DurD } \\
\text { ColD, SorD and DurD }\end{array}$ \\
\hline Asencio & $\begin{array}{l}\text {-fine sandstones; } \\
\text { sandstones with } \\
\text { abundant calcite } \\
\text { cement; and } \\
\text { calcretes/silcretes }\end{array}$ & $\begin{array}{l}\text { Biomphalaria walteri (21) } \\
\text { Biomphalaria reversa (21) } \\
\text { Bulimulus klappenbachi (22) } \\
\text { Ostracoda (22) } \\
\text { Neosauropoda eggshells Sphaerovm erbeni (22) } \\
\text { Characean gyrogonites (22) } \\
\text { Rhizoliths (22) } \\
\text { Titanosauria g. et. sp. indet. (1) }\end{array}$ & $\begin{array}{l}\text { local road near Trinidad City's Hippodrome, FloD* } \\
\text { local road near Trinidad City's Hippodrome, FloD* } \\
\text { local road near Trinidad City's Hippodrome, FloD* } \\
\text { local road near Trinidad City's Hippodrome, FloD* } \\
\text { local road near Trinidad City's Hippodrome, FloD* } \\
\text { local road near Trinidad City's Hippodrome, FloD* } \\
\text { local road near Trinidad City's Hippodrome, FloD* } \\
\text { near Palmitas Town, SorD }\end{array}$ \\
\hline \multirow{17}{*}{ Mercedes } & \multirow{17}{*}{$\begin{array}{l}\text { Middle and top } \\
\text { the unit } \\
\text { (sandstones and } \\
\text { conglomerate } \\
\text { sandstones; } \\
\text { sandstones with } \\
\text { abundant calcite } \\
\text { cement; and } \\
\text { calcretes) }\end{array}$} & Biomphalaria walteri $(10,21)$ & $\begin{array}{l}\text { quarry in Caja Bancaria Logging, PayD*; } \\
\text { quarry in Route } 25 \text { near Algorta Town, RíoD; } \\
\text { shore of Palmar Lake, SorD* }\end{array}$ \\
\hline & & Biomphalaria reversa $(10,21)$ & $\begin{array}{l}\text { quarry in Caja Bancaria Logging, PayD*; } \\
\text { quarry in Route } 25 \text { nearby Algorta Town, RíoD; } \\
\text { shore of Palmar Lake, SorD* }\end{array}$ \\
\hline & & Physa sp. $(10,22)$ & $\begin{array}{l}\text { quarry in Caja Bancaria Logging, PayD*; } \\
\text { quarry in Route } 25 \text { nearby Algorta Town, RíoD* } \\
\text { shore of Palmar Lake, SorD* }\end{array}$ \\
\hline & & Succineidae indet. $(10,22)$ & $\begin{array}{l}\text { quarry in Caja Bancaria Logging, PayD*; } \\
\text { quarry in Route } 25 \text { nearby Algorta Town, RíoD* } \\
\text { shore of Palmar Lake, Soriano Department* }\end{array}$ \\
\hline & & Pupoides (Ischnopupoides) gnocco $(10,20)$ & $\begin{array}{l}\text { quarry in Caja Bancaria Logging, PayD* } \\
\text { quarry in Route } 25 \text { nearby Algorta Town, RíoD* } \\
\text { shore of Palmar Lake, SorD* }\end{array}$ \\
\hline & & Bulimulus klappenbachi $(10,22)$ & $\begin{array}{l}\text { quarry in Caja Bancaria Logging, PayD* } \\
\text { quarry in Route } 25 \text { nearby Algorta Town, RíoD* }\end{array}$ \\
\hline & & Bahiensis priscus (22) & quarry in Caja Bancaria Logging, PayD * \\
\hline & & Eoborus charruanus (22) & quarry in Route 25 nearby Algorta Town, RíoD* \\
\hline & & Ostracoda $(12,22)$ & $\begin{array}{l}\text { quarry in Caja Bancaria Logging, PayD* } \\
\text { shore of Palmar Lake, SorD* }\end{array}$ \\
\hline & & Titanosauria g. et sp. indet. (14) & FlorD. \\
\hline & & Neosauropoda eggshells Sphaerovm erbeni $(9,15)$ & $\begin{array}{l}\text { quarry in Caja Bancaria Logging, PayD* } \\
\text { near Palmitas Town and shore of Palmar Lake, SorD* }\end{array}$ \\
\hline & & Characean gyrogonites (22) & $\begin{array}{l}\text { quarry in Caja Bancaria Logging, PayD* } \\
\text { shore of Palmar Lake, SorD* } \\
\text { quarry in Route } 25 \text { nearby Algorta Town, RíoD* }\end{array}$ \\
\hline & & Celtissantosiendocarps $(12,22)$ & $\begin{array}{l}\text { quarry in Caja Bancaria Logging, PayD* } \\
\text { shore of Palmar Lake, SorD* }\end{array}$ \\
\hline & & Rhizoliths $(15,18)$ & $\begin{array}{l}\text { quarry in Caja Bancaria Logging, PayD* } \\
\text { quarry in Route } 25 \text { nearby Algorta Town, RíoN* } \\
\text { shore of Palmar Lake, SorD* }\end{array}$ \\
\hline & & Celliforma isp. $(15,18)$ & $\begin{array}{l}\text { quarry in Caja Bancaria Logging, PayD, } \\
\text { shore of Palmar Lake, SorD }\end{array}$ \\
\hline & & Pallichnus isp. $(15,18)$ & quarry in Caja Bancaria Logging, PayD \\
\hline & & Rosellichnus isp. $(15,18)$ & quarry in Caja Bancaria Logging, PayD \\
\hline Guichón & & $\begin{array}{l}\text { Saltasauridae g. et .sp. indet. }(2,16) \\
\text { Uruguaysuchus aznarezi }(5,17) \\
\text { Sphaerovum sp. }(18) \\
\text { Iguanodontia g. et sp. indet. }(2,16) \\
\text { Theropoda g. et sp. Indet. }(2,16) \\
\text { Sebecosuchia g.et sp. indet. }(11)\end{array}$ & $\begin{array}{l}20 \mathrm{~km} \text { of Quebracho Ville, PayD } \\
\text { Near Guichón City, PayD } \\
20 \mathrm{~km} \text { of Quebracho Ville, PayD } \\
20 \mathrm{~km} \text { of Quebracho Ville, PayD } \\
20 \mathrm{~km} \text { of Quebracho Ville, PayD } \\
20 \mathrm{~km} \text { of Quebracho Ville, PayD }\end{array}$ \\
\hline
\end{tabular}


Medina et al. (1978) demonstrated the presence of palygorskite associated with the limestones and siliciclastic limestones of the Queguay Formation in the type area.
Recently, Cabrera et al. (2018) proposed a Late Cretaceous age for the Queguay Formation, based on the ubiquitous presence of Neosauropoda eggshells (Sphaerovum erbeni).

\section{METHODOLOGY}

Extensive field work was conducted to define the relationships among the Mercedes, Asencio, and Queguay formations, including those outcrops where earlier authors observed arguable stratigraphic boundaries (Ford \& Gancio, 1989a, b; Tófalo \& Pazos, 2010; Alonso-Zarza et al., 2011). The position of the fossil assemblages described by Cabrera (2015) was verified as well.

The stratigraphy of the key sites was described, logged, and photographed. Detailed cross-sections and geological maps at 1:50.000 and 1:20.000 scales were performed in two key and contiguous quarries, the Queguay quarry (ANCAP, National Administration of Fuels, Alcohol and Portland) and the neighboring White quarry. Representative samples were collected at the Queguay quarry for thin section, mineralogy, and U-Pb geochronology.

Petrographic analyses were performed on 10 thin sections. The samples were partially stained with alizarin Red S to identify calcite and dolomite, and impregnated with blue epoxy for porosity assessments. Samples of carbonates were obtained using a Dremel microdrill at low rpms. Each sample was microdrilled under a magnifying glass to avoid visible clay concentrations and other types of contamination.

X-Ray Diffraction analyses $(n=10$, Queguay quarry) were performed using a Rigaku Geigerflex Power Diffractometer with a Co tube and a graphite monochromator and routine search/match procedures of diffraction patterns using the JCPDS database.

A detailed U-Pb record (8 whole rock samples) was obtained from a measured stratigraphic section. Rock samples were collected at $1 \mathrm{~m}$ intervals.

The carbonate powders were weighed in an ultra-clean room using a UMT2 microbalance and, once transferred to acid-washed Teflon digestion vessels, they were dissolved in $6.2 \mathrm{~N}$ $\mathrm{HCl}$ at $80^{\circ} \mathrm{C}$ for 48 hours. A measured amount of ${ }^{205} \mathrm{~Pb} /{ }^{235} \mathrm{U}$ tracer solution $(7.55 \mathrm{mg})$ was added to the acid mixture prior to digestion. Uranium and lead were purified using an $\mathrm{HBr}$ chromatography procedure (Heaman, 1989).

The purified uranium and lead were loaded onto out-gassed Re-filaments in a mixture of silica gel and phosphoric acid. Their isotopic compositions were determined on a VG354 thermal ionization mass spectrometer (TIMS) at the University of Alberta using a Daly photomultiplier (analogue) detector mode. All errors are reported at the $2 \sigma$ level.

\section{RESULTS}

The results firstly show the regional stratigraphic sections of the Norte Basin in general and, secondly, focus specifically on the key section of the Queguay quarry (geological map, facies profiles, mineralogy, absolute age, and fossiliferous content), representative of the Queguay Formation type area.

\section{Stratigraphic sections}

A summary of the lithostratigraphic relationships of the Late Cretaceous record in the Norte Basin across different outcrops and key profiles is shown in Figure 4 and, additionally, a representative geological section of the stratigraphic relations between the Mercedes and Queguay formations in the type area was elaborated (Figure 5). Figure 2 shows that the Queguay Formation, as defined by Goso \& Bossi (1966), is developed exclusively on the valley of the Queguay River, partially controlled by the homonymous structural lineament, where it exhibits thicknesses that average $10-15 \mathrm{~m}$ and a remarkable lateral continuity (Figures 4 and 5).

The limestones and siliciclastic limestones of the Queguay Formation show a transitional to abrupt lateral passage with the sandstones and conglomeratic sandstones of the Mercedes Formation, and its top is unconformably overlain by the Fray Bentos Formation of middle - late Oligocene age (Figure 6). In general, limestones offer greater resistance to erosion than the surrounding sedimentary rocks, so they control the highest relief in the region. The distribution of the Mercedes-Asencio pair is strongly controlled by the Queguay Lineament. While absent in the northern side of 
the lineament, the pair shows a northwesterndepositional trend smoothly tilted towards the Southwest. All outcrops on key areas exhibit facies and facies associations consistent with the fluvial origin proposed by several authors (Chebli et al., 1989; Goso, 1999; Goso \& Perea,
2003; Tófalo et al., 2001). The concordant contact between the Mercedes and Asencio formations and their relation to the Early Cretaceous sediments and the basement is very well exposed and defined in several outcrops (Figure 4).

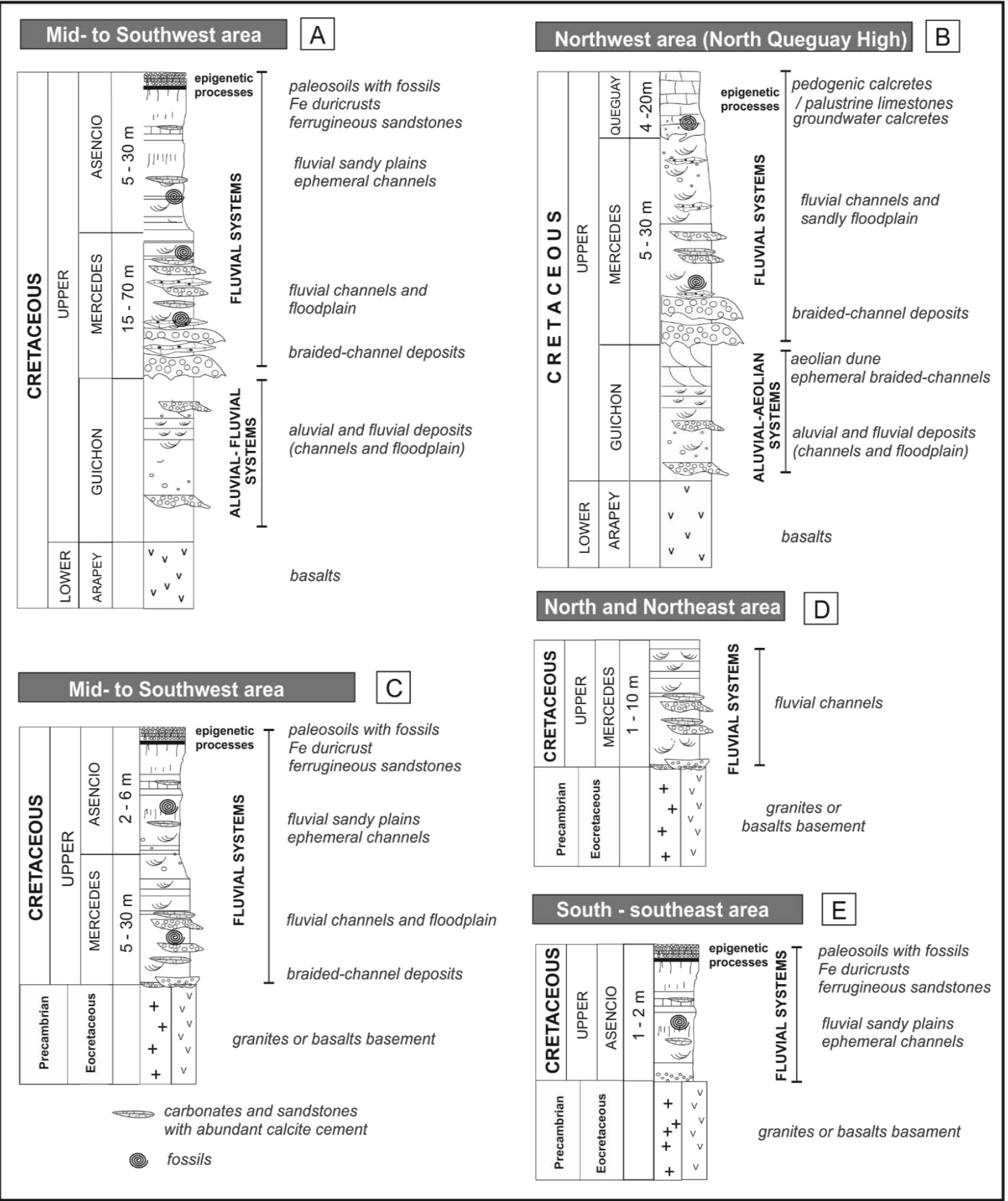

Figure 4 - Schematic geological profiles of the Norte Basin depicting the stratigraphic relations within the Late Cretaceous record. A) Representative geological profile of the route 26 section; B) geological profile representative of Paysandú and Río Negro departments, e.g. route 90 - 25 Guichón - Piedras Coloradas; Algorta - Menafra; C) Río Negro (SW) and Soriano departments, e.g. route 2 Cardona - Mercedes, route 14 from Vera to Cololó creeks, D) Salto, Tacuarembó, Paysandú, Durazno and Flores departments, e.g. route 25, Tres Árboles-Merinos; 280 km route 5; Daymán river and Totoral creek sector; route 14, near Villa del Carmen, Grutas del Palacio; E) Durazno, Florida and Flores, Grutas de Carlos Reyles, South of Trinidad. 
Thin levels of calcretes are found at different stratigraphic positions of the Mercedes-Asencio pair, particularly in the middle and upper section of the Mercedes Formation (see Lambert, 1940; Serra, 1945; Bossi et al., 1975; Veroslavsky et al., 1997).

Those calcretes present in the Asencio Formation were defined as Algorta Member by Preciozzi et al. (1985). Additionally, some lateritic levels from the Asencio Formation were verified to be partially affected by calcretization processes (Figure 5).

\section{The Queguay quarry section}

The Queguay quarry (ANCAP property) is located (UTM X = 419809, $\mathrm{Y}=6448526$ ) very close to the intersection of routes 3 and 26 in the
Paysandú Department, and the geological map and representative stratigraphic section of this region is shown in Figure 6.

\section{Lithofacies description}

Stratigraphic sections are shown in Figure 7. Lithofacies at the Queguay quarry site are white massive to micritic limestones with floating quartz sand-sized grains. The calcrete profile, which is developed as a single cycle within the sand host sediments, is around $4 \mathrm{~m}$ thick. Most of the host rock has been replaced by carbonates, despite the fact that in some areas the calcretic groundmass still preserves the original sand texture, and relicts of the Mercedes Formation siliciclastic sandstones appear randomly throughout the section (Figure 4).

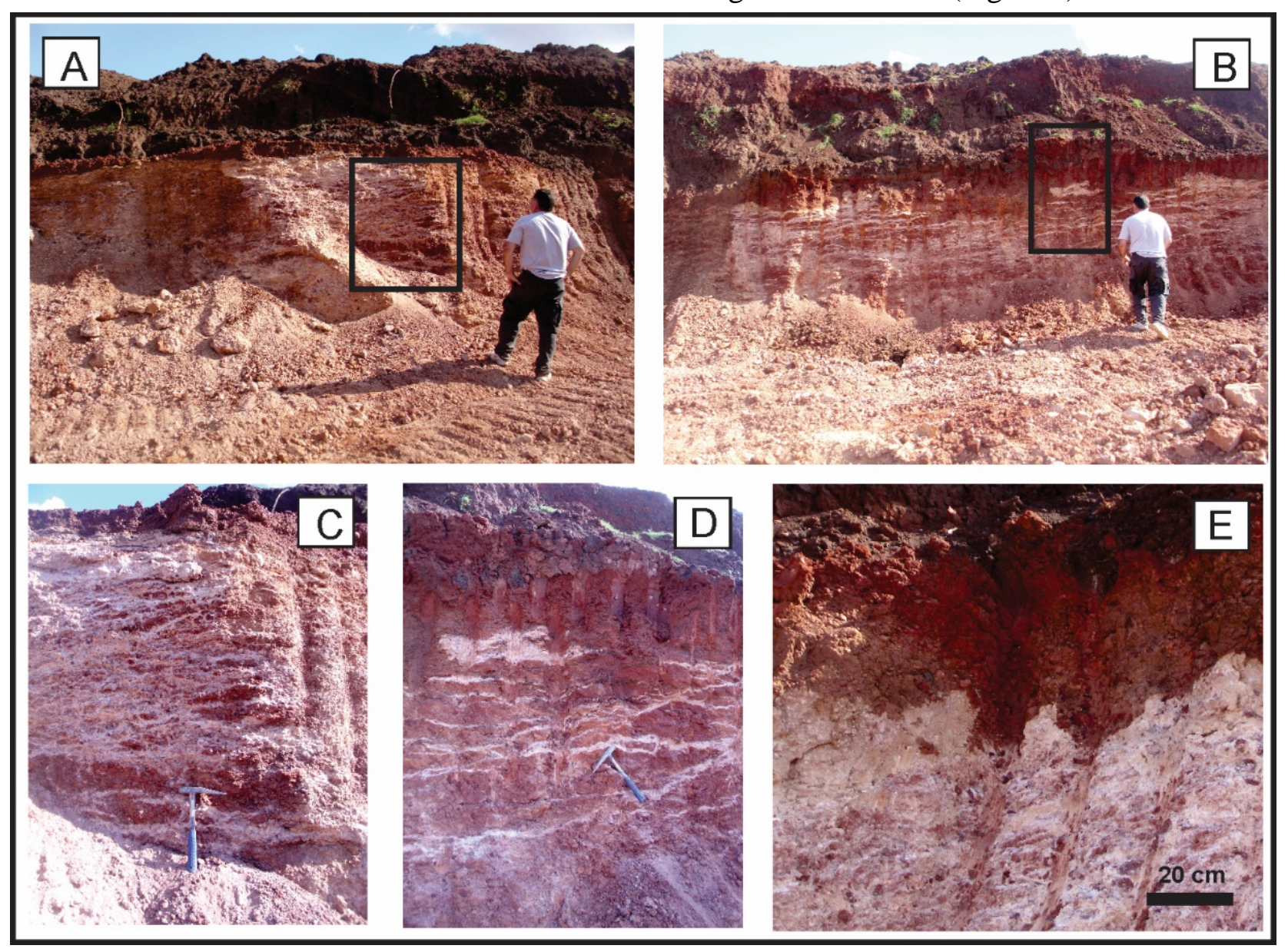

Figure 5 - Example of pedogenic and diagenetic processes affecting the Asencio Formation. A) and B) General view of the Asencio sandstones overprinted by ferrugination and carbonation processes. C) and D) close view of A) and B) respectively, showing selective replacement of ferruginous sandstones by carbonates. Laminar carbonate horizons covering the host and generating the appearance of "laterite clasts" embedded in a carbonate matrix. E) Irregular contacts product of the selective replacement by carbonates. Outcrop location: UTM X $=408595, \mathrm{Y}=6315841$ (Soriano Department).

Laminar texture in the limestones is only seen at the top of the section, where very thin horizontal to sub-horizontal layers of silica are found (Figure 9).

Root traces were not found anywhere in the massive and even laminar calcrete horizons.
Complete calcrete profiles are only recognized in few sections. XRD results indicate that calcite is the main carbonate, and that calcite+quartz+palygorskite is the only mineral assemblage present in all the samples at the Queguay quarry site (Figure 4). 


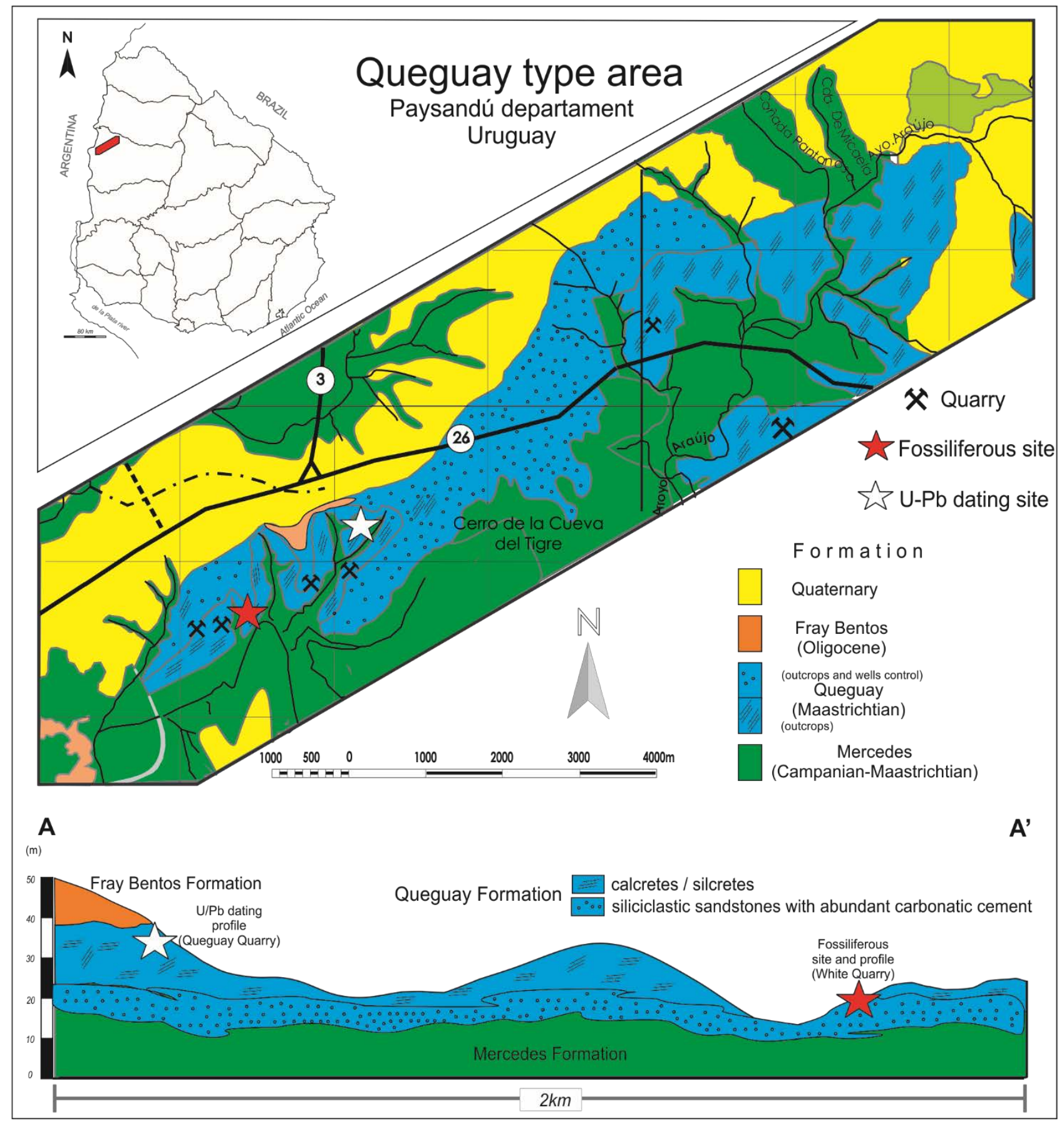

Figure 6 - Geological map of the Queguay river valley region in Paysandú Department (modified from Preciozzi et al., 1983; and Veroslavsky \& de Santa Ana, 2004) and simplified cross-section showing the stratigraphic relations of the Mercedes and Queguay formations at the site of the collection of samples for geochronology and fossiliferous study.

\section{General micromorphological features}

Microscopic study supported by lithofacies analysis of the host rocks showed the occurrence of two textural classes. These are fine- to coarse-grained sandstones composed of moderately-sorted siliciclastic framework grains, mainly monocrystalline and polycrystalline quartz, floating in carbonate (calcite) cement. The distribution pattern of quartz grains might suggest that calcretization is responsible for the extensive replacement of the host matrix, displacement, and partial replacement of framework grains.
Micrite forms in most of the samples, making up the bulk of the thin sections, which suggests that carbonate precipitation was relatively rapid. In some places, it locally aggrades to microsparite with sparry calcite precipitation around pisoids and fractures. Pisoids are not major components but are present in most of the section. They are mainly structureless or formed by a groundmass of detrital grains cemented by carbonates ranging in size from $500 \mu \mathrm{m}$ to a few millimeters.

Light brown rings of micritic calcite coat quartz sand grains, which might indicate that 
they were rolling while the cement was precipitating around the sand grain nuclei.

As regards cementation, some samples are mainly composed by a simple alpha fabric, comprising massive, structureless, pore-filling micritic calcite. Calcite cement fabrics include also drusy mosaic and blocky cements (Figure 7). Calcite veins cross-cut randomly, and are filled by sparite or microsparite, depending on the width of the veins. Different types of silica (chalcedony, opal) occur as fracture and voidfilling cements.

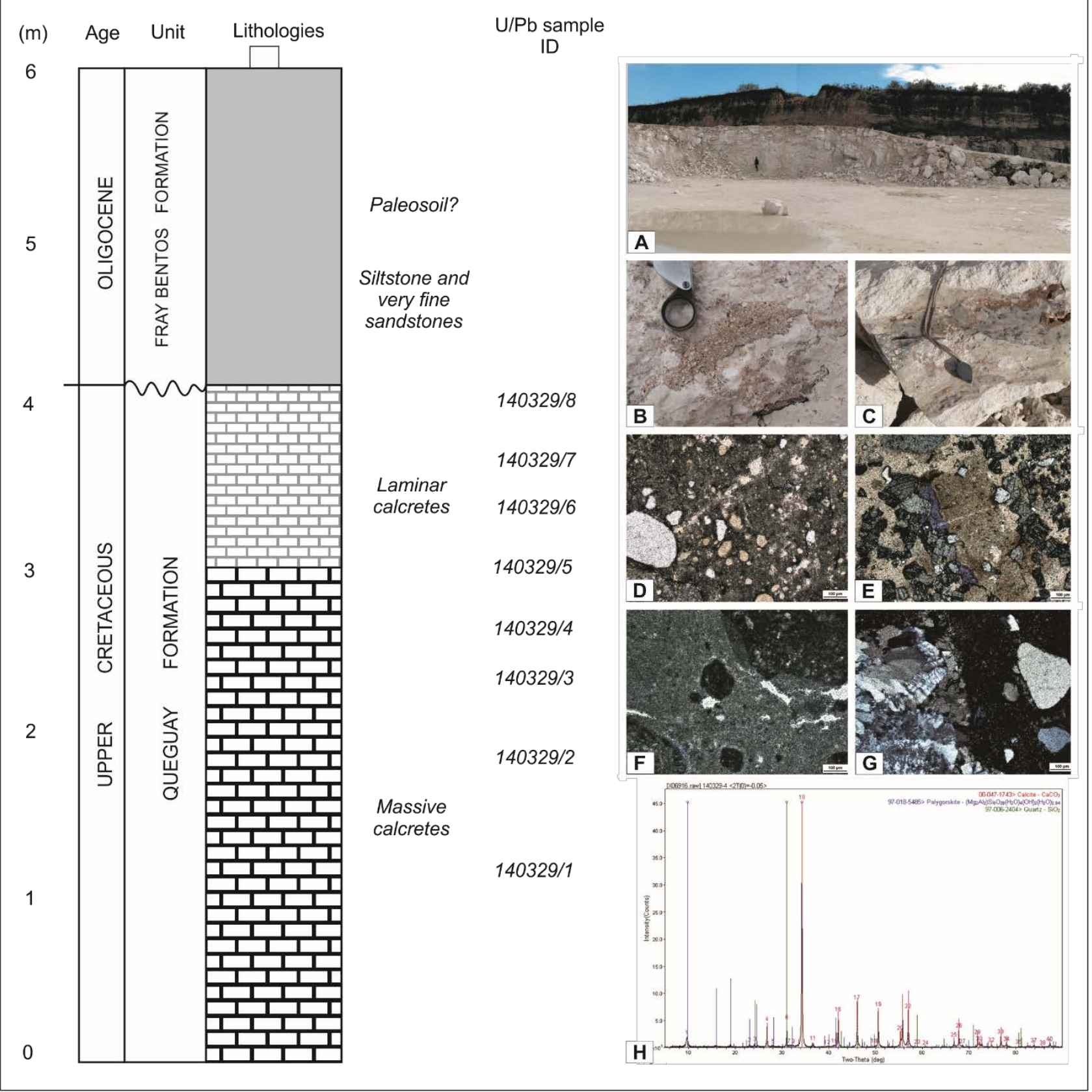

Figure 7 - Stratigraphic profile of the Queguay Formation in the type section (Queguay quarry) and sample location. A) General view of the quarry; B) close-up view of partially carbonate-cemented host sandstones and, C) partially silcretized massive calcrete. Thin section photographs: D) quartz grains floating in micritic calcite groundmass; E) calcrete with development of secondary porosity infilled by sparite; F) nodular calcretes with secondary porosity cemented with silica; G) micritic calcretes with two generations of silica (chalcedony + quartz) and sparite infilling fractures. All thin sections are crossed nicols. H) XRD pattern of bulk minerals of massive calcretes (sample 140329-4). Mineral assemblage: calcite+quartz+palygorskite.

\section{$U-P b$ geochronology}

The reliability of carbonate $\mathrm{U}-\mathrm{Pb}$ geochronology strongly depends on the quality of the samples (i.e., lack of significant postdepositional alteration, suitable $\mathrm{U}$ and $\mathrm{Pb}$ concentrations, and lack of detrital contamination). Accordingly, the selection of whole rock carbonate samples for this study was mainly based on the preservation of the original petrographic textures and the variation of the 
$\mathrm{U} / \mathrm{Pb}$ ratios and $\mathrm{U}$ and $\mathrm{Pb}$ concentrations at different stratigraphic intervals. The U-Pb results are presented in Table 2.

$\mathrm{U}$ concentrations are relatively homogeneous, ranging from 0.38 to $0.87 \mathrm{ppm}$, whereas $\mathrm{Pb}$ concentrations range from 0.60 to $8.54 \mathrm{ppm}$. The $\mathrm{Th} / \mathrm{U}$ values of the calcrete samples vary between 3.2 and 12.2 (Table 2). Corresponding ${ }^{238} \mathrm{U} /{ }^{204} \mathrm{~Pb}$ ratios range from 3.56 to 63.45 . The ${ }^{206} \mathrm{~Pb} /{ }^{204} \mathrm{~Pb}$ vs. ${ }^{238} \mathrm{U} /{ }^{204} \mathrm{~Pb}$ results are plotted in Figure 9 and display some scatter.

Three samples (A, B, D) are collinear and define a ${ }^{238} \mathrm{U}-{ }^{206} \mathrm{~Pb}$ isochron the slope of which corresponds to an age of $71.7 \pm 9.0 \mathrm{Ma}$ and a mean square of the weighted deviates (MSWD) equal to 0.53 .

The initial ${ }^{206} \mathrm{~Pb} /{ }^{204} \mathrm{~Pb}$ ratio defined by this regression line is a relatively unradiogenic value of $17.76 \pm 0.02$. If the calcrete $\mathrm{U}-\mathrm{Pb}$ regression line is geologically meaningful then this unradiogenic initial $\mathrm{Pb}$ isotopic composition is a feature of the fluids that precipitated the carbonate. The scatter shown by the other samples about this regression line could reflect post-depositional redistribution of $\mathrm{U}$ and/or $\mathrm{Pb}$ (samples that plot below the line) and some detrital component (samples that plot above the line).

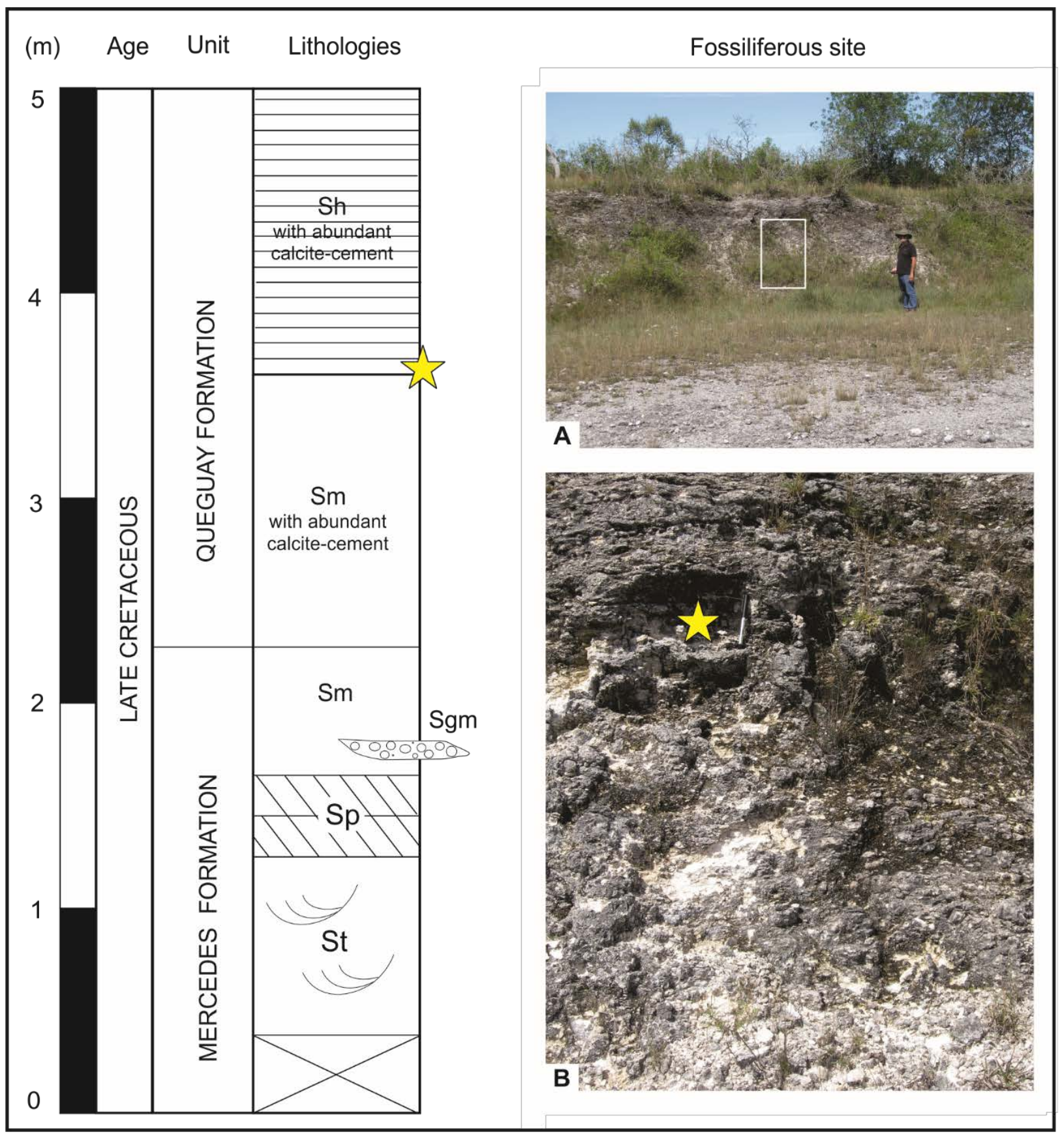

Figure 8 - White quarry (red star in Figure 6 - UTM X =418032, Y= 6447948), where the contact between the limestones of the Queguay Formation and the siliciclastic sandstones with abundant calcite cement is observed. At this location, insect nests, rhizoliths and dinosaur egg remains are found on the same stratigraphic level. Yellow star $=$ fossil site. 
Table 2 - U-Pb data for calcretes of the Queguay Formation at type section (see stratigraphic profile of Figure 7 for samples location).

\begin{tabular}{|c|c|c|c|c|c|c|c|c|c|c|c|c|c|c|c|c|c|}
\hline \multirow[b]{2}{*}{ Sample } & \multirow[b]{2}{*}{$\begin{array}{c}\mathrm{U} \\
(\mathrm{ppm})\end{array}$} & \multirow[b]{2}{*}{$\begin{array}{c}\text { Th } \\
\text { (ppm) }\end{array}$} & \multirow[b]{2}{*}{$\begin{array}{c}\mathrm{Pb} \\
(\mathrm{ppm})\end{array}$} & \multirow[b]{2}{*}{ Th/U } & \multirow[b]{2}{*}{$\begin{array}{c}\text { TCPb } \\
\text { (pg) }\end{array}$} & \multirow[b]{2}{*}{$\begin{array}{c}{ }^{206} \mathrm{~Pb} / \\
{ }^{204} \mathrm{~Pb}\end{array}$} & \multirow[b]{2}{*}{ 1s } & \multirow[b]{2}{*}{$\begin{array}{l}{ }^{238} \mathrm{U} / \\
{ }^{204} \mathrm{~Pb}\end{array}$} & \multirow[b]{2}{*}{ 1s } & \multirow[b]{2}{*}{$\begin{array}{c}{ }^{206} \mathrm{~Pb} / \\
{ }^{238} \mathrm{U}\end{array}$} & \multirow[b]{2}{*}{ 1s } & \multicolumn{2}{|c|}{$\begin{array}{l}\text { Model Age } \\
\text { (Ma) }\end{array}$} & \multicolumn{4}{|c|}{ Isochron Plot } \\
\hline & & & & & & & & & & & & $\begin{array}{c}{ }^{206} \mathrm{~Pb} / \\
{ }^{238} \mathrm{U}\end{array}$ & 1s & $\mid{ }^{238} \mathrm{U} /$ & 1s & $\begin{array}{l}{ }^{206} \mathrm{~Pb} / \\
{ }^{204} \mathrm{~Pb}\end{array}$ & 1s \\
\hline 101021/A & 0,42 & 1,47 & 3,30 & 3,48 & 13656 & 17,851 & 0,006 & 7,98 & 0,01 & 0,33707 & 0,02014 & 1872,5 & 96,4 & 7,98 & 0,01 & 17,851 & 0,006 \\
\hline 101021/B & 0,86 & 2,74 & 1,47 & 3,18 & 29277 & 18,157 & 0,030 & 36,87 & 0,26 & 0,08129 & 0,00442 & 503,8 & 26,3 & 36,87 & 0,26 & 18,157 & 0,030 \\
\hline 101021/C & 0,87 & 3,03 & 0,86 & 3,50 & 5669 & 18,332 & 0,008 & 63,45 & 0,10 & 0,02555 & 0,00294 & 162,7 & 18,4 & 63,45 & 0,10 & 18,332 & 0,008 \\
\hline 101021/D & 0,59 & 7,18 & 1,53 & 12,22 & 3245 & 18,039 & 0,014 & 24,24 & 0,04 & 0,00501 & 0,01560 & 32,2 & 99,3 & 24,24 & 0,04 & 18,039 & 0,014 \\
\hline $101021 / \mathrm{E}$ & 0,38 & 1,73 & 1,43 & 4,56 & 8905 & 18,392 & 0,009 & 16,85 & 0,02 & 0,02813 & 0,01711 & 178,8 & 106,4 & $\mid 16,85$ & 0,02 & 18,392 & 0,009 \\
\hline $101021 / \mathrm{F}$ & 0,59 & 5,41 & 0,60 & 9,19 & 2690 & 18,630 & 0,011 & 63,41 & 0,10 & 0,00271 & 0,03922 & 17,4 & 247,4 & |63,41 & 0,10 & 18,630 & 0,011 \\
\hline 101021/Ff & 0,65 & 2,52 & 0,81 & 3,90 & 12348 & 18,543 & 0,008 & 50,72 & 0,15 & 0,02907 & 0,00381 & 184,7 & 23,8 & 50,72 & 0,15 & 18,543 & 0,008 \\
\hline $101021 / \mathrm{G}$ & 0,49 & 1,76 & 8,54 & 3,60 & 93692 & 17,708 & 0,022 & 3,56 & 0,04 & 0,43749 & 0,05117 & 2339,4 & 225,5 & | 3,56 & 0,04 & 17,708 & 0,022 \\
\hline
\end{tabular}

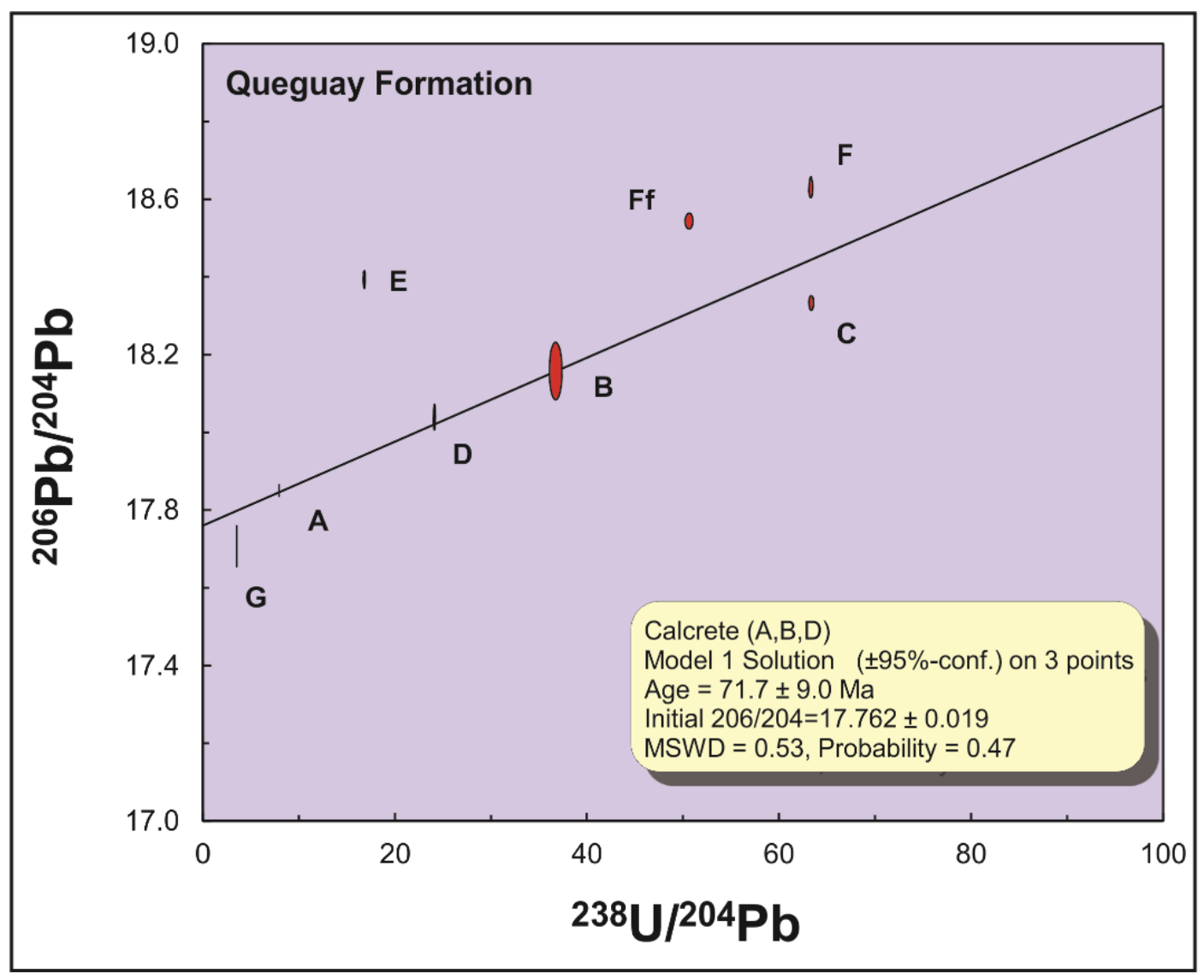

Figure 9 - U-Pb isochron diagram for calcretes of the Queguay Formation.

\section{DISCUSSION}

\section{Lithostratigraphy}

According to the International Stratigraphic Guide "lithostratigraphic units are defined and recognized by observable physical features and not by their inferred age, the time span they represent, inferred geologic history, or manner of formation" and "the name of a stratigraphic unit, once applied and then abandoned, should not be revived except in its original sense"

Ignorance of these simple principles is the basis of a long-lasting confusion about the Late
Cretaceous units in Uruguay. Unfortunately, the removal of good practices in stratigraphy occurred despite the fact that the lithostratigraphic units were well defined by their lithologies and stratigraphic relationships in the pioneer geological works (e.g. Lambert, 1939, 1940; Serra, 1945; Bossi, 1966; Goso \& Bossi, 1966).

The Late Cretaceous record of the Norte Basin exemplifies a case of stratigraphic discrepancies as the literature published over the 
past 30 years contains different approaches for the formal definition of its units. The main (lithostratigraphic) problem of some authors has been a perceived difficulty distinguishing between carbonates of the Queguay Formation and carbonates of the Mercedes and Asencio formations, and their significance and hierarchy in lithostratigraphic proposals.

A similar situation occurs with the ferruginous sandstones, paleosols and duricrust of the Asencio Formation, where the origin, processes and fossiliferous content conditioned the different and controversial lithostratigraphic proposals (see Morras et al., 2010).

In relation to carbonate cementing processes, by definition, the three formations represent continental deposits with centimetric to metric levels of carbonates (limestones and carbonatecemented sandstones) interbedded with siliciclastic sandstones, but while the Mercedes and Asencio formations (Lambert, 1939, 1940; Bossi et al., 1975; Preciozzi et al., 1985 and others) are widely distributed along the western part of the basin, the Queguay Formation is restricted to the valley of the Queguay River (Goso \& Bossi, 1966).

This implies that all other Late Cretaceous carbonates that occur beyond this region should be assigned as being either a component of the Mercedes or Asencio formations (Bossi et al., 1975; Preciozzi et al., 1985).

The other issue is that the fossiliferous content, origin and age of the calcretization event have been used to modify the primary definition of the units. Taking all these facts into account, a review of the evolution of the stratigraphic terminology is needed, in order to gain a better understanding of the issues and misleading conclusions regarding the study of the Late Cretaceous record of the Norte Basin.

Since the initial reports describing Uruguayan geology (e.g. Walther, 1919, 1930, 1933; Heune, 1929; Frenguelli, 1930), the presence of abundant carbonate cement and limestone layers interbedded with the "sandstones with dinosaurs" (now Mercedes and Asencio formations) has been recognized.

More recently, Bossi et al. (1975) observed that several calcareous lenses and sandy limestones were present at different stratigraphic levels in the Mercedes Formation. Additionally, Preciozzi et al. (1985) identified the calcareous lithologies of the Asencio
Formation and grouped them into the Algorta Member.

Goso (1999) and Goso \& Perea (2003) proposed to disregard the Asencio Formation, transferring its lithologies to the Mercedes Formation and consequently redefining the unit. In this regard, we believe that it is meaningful to preserve the Mercedes and Asencio formations in the stratigraphy of the Norte Basin because their lithologies and stratigraphic boundaries are clearly recognizable and mappable, as seen in all published geological cartography of Uruguay (Bossi et al. 1975; Preciozzi et al. 1985; Ford, 1998; Ford \& Gancio, 1989a, b; Bossi \& Ferrando 2001).

Moreover, the differences among the Mercedes, Asencio, and Queguay formations have economic implications in the field of mineral and groundwater exploration. Furthermore, the Mercedes Formation is the main aquifer in the Western region of Uruguay, while the Asencio Formation has a low potential aquifer or an aquitard behavior (Montaño et al. 2004).

The Queguay Formation is the only example of sedimentary rocks used for lime and cement production in the country.

On the other hand, new stratigraphic definitions for the Asencio and Queguay formations were proposed by Alonso-Zarza et al. (2011). Based on the study of 3 key sections, their fossil content and diagenesis extent, the authors redefined the units by age assigning an Early Eocene interval and Middle Eocene-Middle Oligocene age for the deposition of the Asencio and Queguay formations respectively. There are two major issues regarding these findings.

One is that the Asencio Formation is not present to the north of the Queguay River (Figures 2 and 4, see Preciozzi et al. 1985, Bossi \& Ferrando 2001) and, in consequence, the stratigraphic observations made by AlonsoZarza et al. (2011) are not reliable. Additionally, there is a lack of biostratigraphic significance in the described fossil assemblages of the Queguay limestones (calcretes) and the ferruginous paleosols of the uppermost levels of the Asencio Formation and, consequently, there is no evidence to support the new stratigraphic scheme proposed.

As recently shown by Cabrera (2015) and Cabrera et al. (2018) (Figure 10), after correcting some taxonomic errors presented by 
Alonso-Zarza et al. (2011), the fossil assemblages are nearly identical in all limestones (calcretes) of the Mercedes, Asencio and Queguay formations (see Table 2).
tHIS is in agreement with the penecontemporaneous significance of the fossils indicated by Martínez \& Veroslavsky (2004) and Tófalo \& Pazos (2010).

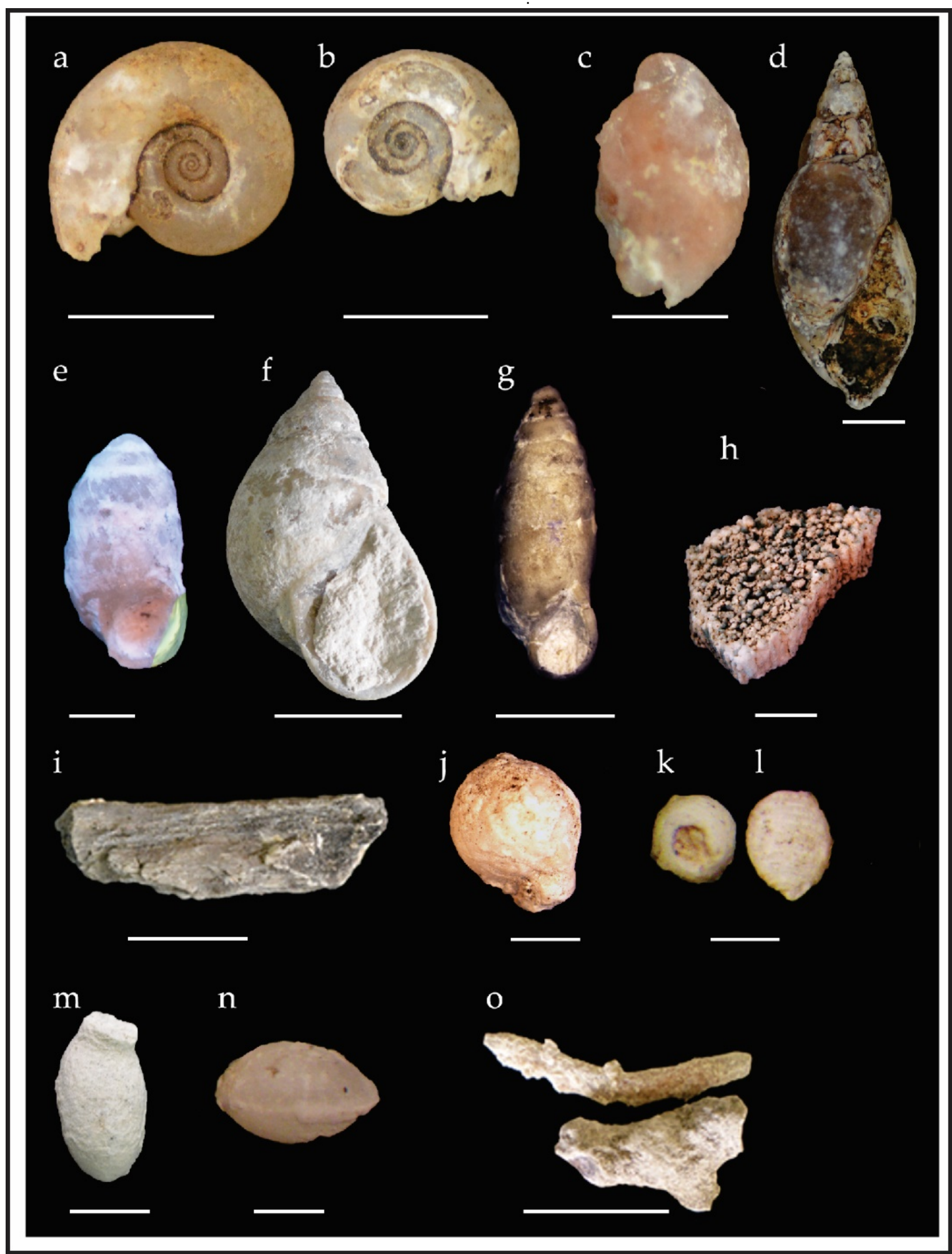

Figure 10 - Fossils from the Queguay Formation. a Biomphalaria walteri* FCDP-I 6457 (scale: 5 mm); b B. reversa* FCDP-I 7220 (scale: 5 mm); c Succineidae indet.* FCDP-I 6467 (scale: 5 mm); d Bulimulus klappenbachi* FCDP-I 6459 (scale: $5 \mathrm{~mm}$ ); e Pupoides (Ischnopupoides) gnocco* FCDP-I 7258 (scale: $1 \mathrm{~mm}$ ); f Eoborus charruanus* FCDP-I 7068 (scale: 5 mm); g Bahiensis priscus* FCDP-I 6474 (scale: $5 \mathrm{~mm}$ ); h Neosauropoda eggshell $\dagger$ FCDP-V 2884 (scale: $5 \mathrm{~mm}$ ); i wood fragment*† FCDP-B 38 (scale: $5 \mathrm{~cm}$ ); j Celtis santosi endocarp* FCDP-B 25 (scale: 5 mm); k-l gyrogonites* FCDP-B 45 (scale: $500 \mu \mathrm{m}$ ); m insect pupal chamber*† (scale: $5 \mathrm{~mm}$ ); $\mathrm{n}$ Ostracoda indet. FCDP-I 7279 (scale: $500 \mu \mathrm{m}$ )* (scale: $2 \mathrm{~mm}$ ); rhizoliths*† (scale: $5 \mathrm{~cm}$ ). * near Villa Quebracho, Paysandú Department, $†$ near the intersection of route 90 with route 25 and at the White Quarry, Paysandú Department. 
During this study, the strong carbonate cementation event in the ferruginous sandstones and laterites of the Asencio Formation previously described by Goso (1999) and Alonso-Zarza et al. (2011) was recognized, as well as the penecontemporaneous character of the calcretization process with at least some ferruginous paleosols (Figure 6).

If we consider that calcretization is a main regional event (Marília Formation, Maastrichtian), and that the age of the process is around $72 \mathrm{Ma}$ - as given by our best estimate of the U-Pb carbonate formation date - then we can extend the Late Cretaceous character to the contemporaneous ferruginous paleosols.

Age ranges are also confirmed by biostratigraphy and their fossiliferous content; the $\mathrm{U}-\mathrm{Pb}$ data is congruent with the presence of Cretaceous dinosaurs in the Asencio Formation (Huene, 1929; Walther, 1933; Mones, 1980; Bossi, 1966; Soto \& Perea (2011a, b). The ichnofossil assemblages described in the ferruginous paleosols of the Asencio Formation (Roselli, 1939, 1987; Genise \& Bown, 1996; and others) do not have any biostratigraphic significance, and indeed cannot be used to define the age of the uppermost levels of the unit by a non causa pro causa inference, as pretended by Alonso Zarza et al. (2011). We consider that present stratigraphic discrepancies, confusion over correlation, and contentious problems relating to stratigraphic nomenclature and formal redefinition can be resolved by preserving the original lithostratigraphic definition. Here, we suggest reverting to the original stratigraphic proposal and using the traditional geological scheme proposed by Bossi (1966) and Goso \& Bossi (1966), who defined the Late Cretaceous record of the Norte Basin on the basis of lithological properties, field relationships, and mappable character of its units. This scheme would only require small adjustments in the lithological description and the modification of the Queguay Formation age (Figure 10).

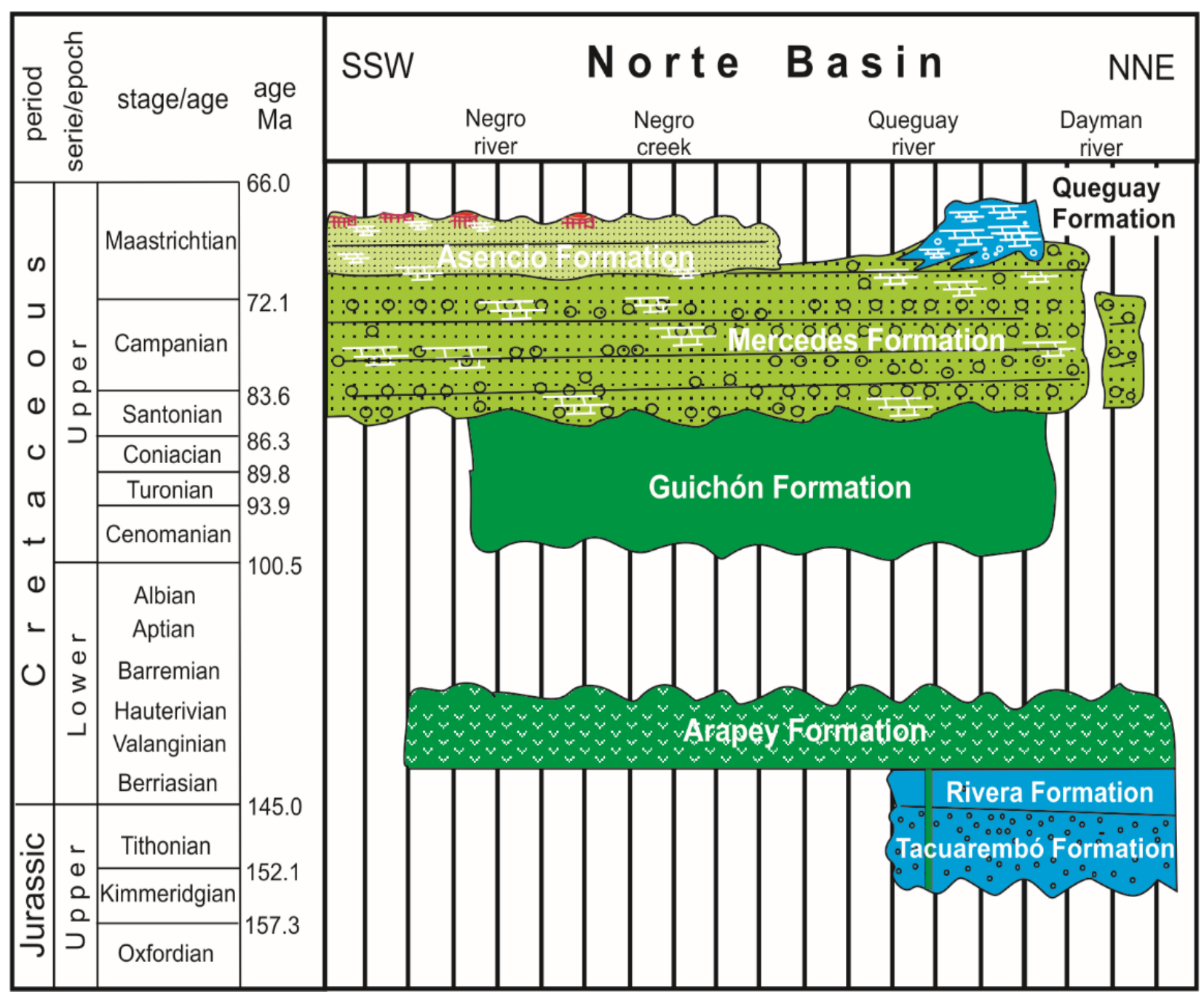

Figure 11 - Lithostratigraphic column proposed for the Late Cretaceous of the Norte Basin that reassesses the pioneering proposals of Bossi (1966) and Goso \& Bossi (1966). The lithostratigraphic separation of Guichón, Mercedes and Asencio has prevailed in the majority of geological maps. 


\section{Non-pedogenic calcretization in the Late Cretaceous}

During the Maastrichtian, groundwater and pedogenic calcretization affected the different cycles of the siliciclastic fluvial successions (Tófalo \& Pazos, 2010; Alonso-Zarza et al., 2011).

The resulting carbonates are thus variable in distribution, composition, texture, geometry, and thickness. Such variation is closely related to the original properties of the host rock, topography, drainage system, and the flow pattern of the groundwater rich in calcium-carbonate (Wright \& Tucker, 1991).

Calcretization was more efficient in the surroundings of the Queguay River valley, where the generation of massive and thick limestone banks (Queguay Formation) was favored by the stratigraphic features of the host rock, the unconsolidated character of the (fluvial) sediments (Lee \& Gilkes, 2005) and the structural characteristics of the region (Veroslavsky et al., 1997).

Here, the calcrete profile has vertical gradation maturation from a non-calcretized host (Mercedes fluvial sandstones) at the base, followed by a massive calcrete horizon (Queguay Formation), and incipient laminar levels at the top (Figures 3 and 7).

In the studied section, the Queguay Formation (Figure 7) does not exhibit the wellorganized features of the calcretes formed in soils (Arakel \& McConchie, 1982; Arakel, 1986; Tandon \& Andrews, 2001).

The scarcity of episodes of brecciation and pisolitic textures and the presence of a thick profile of carbonates $(<5 \mathrm{~m})$ with crystalline (alpha) fabrics (Tófalo \& Pazos, 2010) are indicative of a non-pedogenic origin (Wright, 1990). Groundwater carbonates typically have a micritic and densely crystalline fabric (Figure 7) which often contains dissolution features and shrinkage cracks (Wright \& Tucker, 1991). The associated mineralogy of these calcretes is represented by authigenic silica and authigenic clays (smectite, sepiolite or palygorskite) (Wright \& Tucker, 1991).

It is well known that calcretes develop in climatic zones with a seasonal moisture deficit, allowing calcium carbonate to accumulate (Halitim et al. 1983; Grevenitz,
2006,). In such terrestrial settings, palygorskite has been used as an indicator of seasonal semi-arid and arid environments associated with pedogenic carbonates (Rodas et al., 1994, and references therein). However, in the Queguay type section, palygorskite is associated with nonpedogenic calcretes.

Strong evaporation under seasonal semiarid climate (Fedoroff \& Courty, 1989; Klappa, 1983; Galán \& Pozo, 2011) might enhance the salinity of the surface waters, which can infiltrate in areas of drainage convergence and mix with a more superficial groundwater table thus forming palygorskite and explaining its presence in horizons where non-pedogenic calcretes occur.

Preferential formation of groundwater and phreatic carbonates occur in areas where surface drainages converge, flow gradients decrease, and/or permeabilities are low (Wright \& Tucker, 1991).

The present-day surface drainage system, in the region where the Late Cretaceous sedimentary rocks occur (Figure 2), shows a general East-West to Southwestern pattern that coincides with the overall western-wards trend of the present-day regional groundwater flow system (Heinzen et al., 2003).

Since the major drainage systems in the inland (cratonic) areas can be traced back to Late Cretaceous times (Goso \& Perea, 2003), then we can argue that the regional groundwater paleo-fluid directions equal present-day trends.

Occurrence of groundwater aquifers can explain the distribution of the non-pedogenic calcretes.

The Mercedes aquifer, whose distribution is very well known, is made up of sandstones from the homonymous Formation and it supplies water for the Southwestern area of Uruguay (Manganelli et al., 2007). Variations in the geometry of the aquifer follow the paleotopography at the base of the Late Cretaceous, with larger aquifer thickness in the paleo-valleys dominated by fluvial deposits, and much thinner and isolated aeolian deposits in paleo-uplands. The lateral alteration of groundwater systems can create ribbon-like bodies or valley calcretes (Figure 12), which are responsible for inverted relief if erosion of the surrounding less carbonate-cemented deposits occurs (Nash \& McLaren, 2003). 


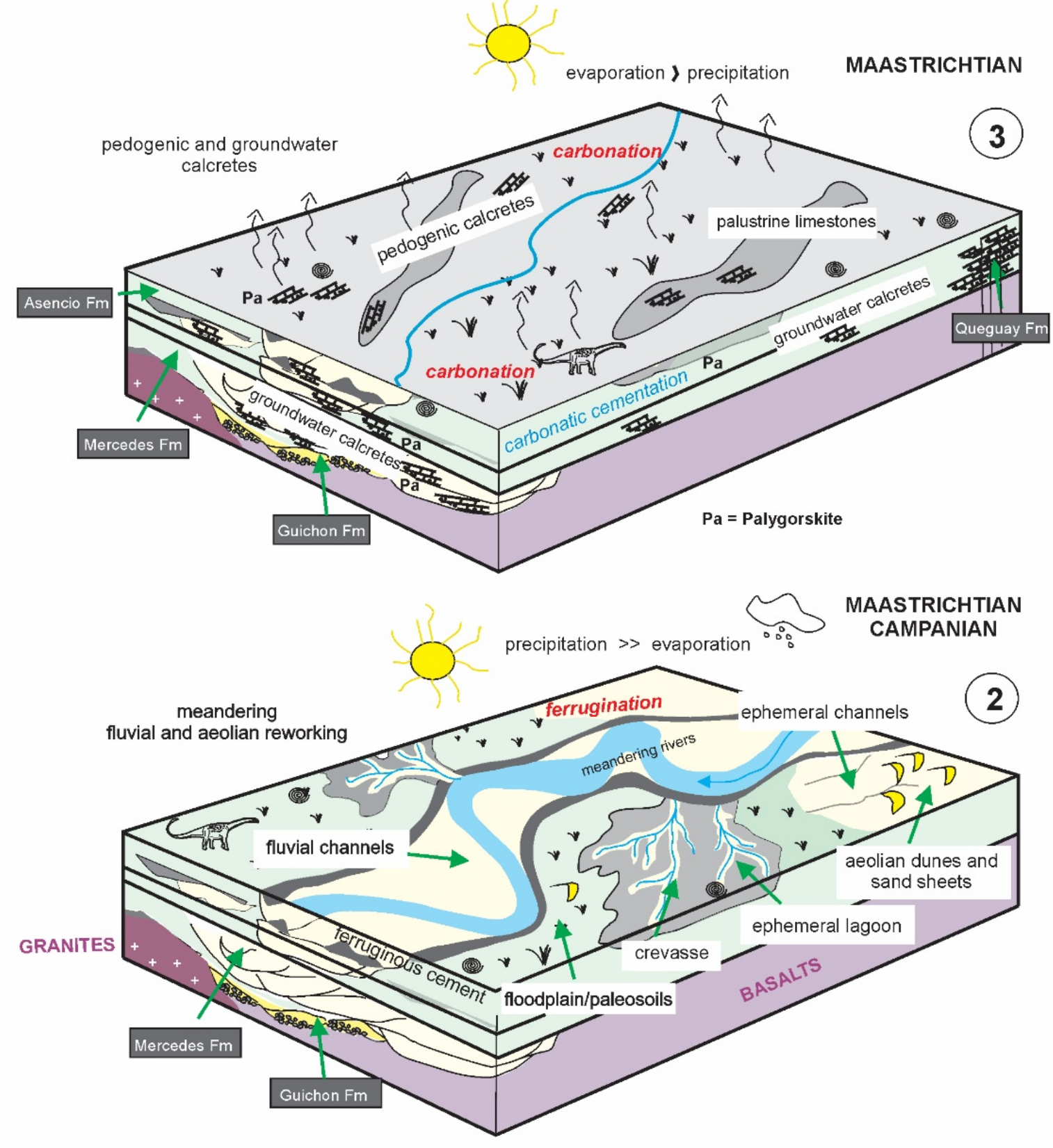

CAMPANIAN

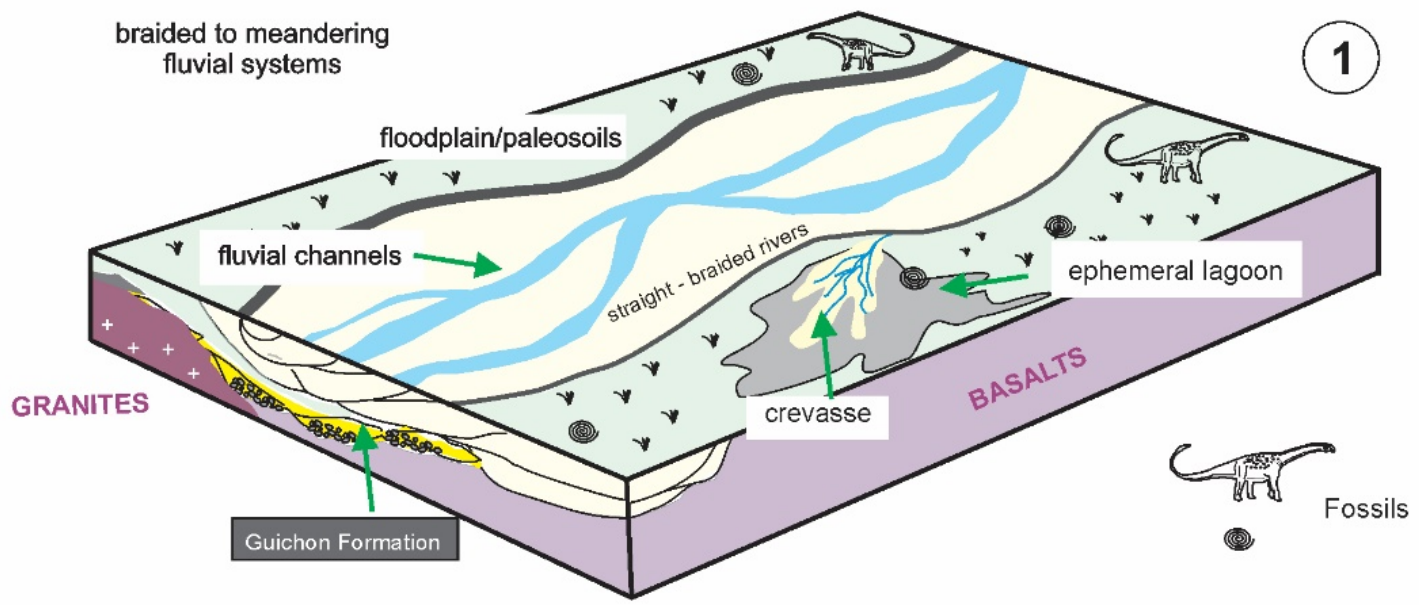

Figure 12 - Evolution model of the Late Cretaceous sedimentary processes based on the mineralogy, facies, lithostratigraphic units, fossiliferous content, and absolute age of the calcretization processes in the Norte Basin. 
Because of the generally smooth topography throughout (moderate relief, subtle slopes), most fluids drain internally to the Queguay river valley, allowing calcretes to develop within a restricted area in the past. Massive and thick calcretes were formed in the sand-channels of the fluvial systems while thinner and more laminated carbonate horizons precipitated in the paleo-flood plain deposits areas. Such carbonates represent lateral facies variation and not an alternation of pedogenic and non-pedogenic calcretes (Alonso-Zarza, 2003).

Definition of the age of the calcretization process is one key aspect of the Late
Cretaceous stratigraphy of the Norte Basin. As previously shown, ages were defined based on the use of ambiguous fossil assemblages and a misunderstanding of the stratigraphy (see Cabrera et al., 2018).

Considering the direct $\mathrm{U}-\mathrm{Pb}$ date obtained in this study for the massive calcretes from the type section, an $\sim 72$ Ma age for early diagenetic carbonate precipitation coincides with the prevailing arid conditions at the Mesozoic-Cenozoic boundary, the ages of the fossil assemblages described in correlative outcrops (Cabrera et al., 2018) and those defined for the Marília calcretes in the Bauru Basin (Da Silva et al., 2017)

\section{CONCLUSIONS}

We consider that the original lithostratigraphic definitions of Bossi (1966) and Goso \& Bossi (1966) for the Mercedes, Asencio and Queguay formations are valid. The three units show very well defined lithological attributes and stratigraphic relationships. They are mappable at surface and subsurface scale and can be used as a tool for mineral and groundwater exploration and management. While the Mercedes Formation appears all along the Midwestern area of the Norte Basin, the Queguay Formation is restricted to the Queguay river valley area where the Asencio

\section{Formation is absent.}

The Maastrichtian age of the calcretization process is supported by the relationship between the fossil assemblages and carbonate diagenesis, the absolute radiometric date of $\sim 72 \mathrm{Ma}$ obtained by the U-Pb method on Queguay limestone samples, and the analogous record of the Bauru Basin. The timing between the laterization and calcretization processes affecting the Asencio Formation is still under debate and additional information is needed to unravel the issue.

\section{ACKNOWLEDGMENTS}

The authors wish to thank PEDECIBA (National Program for the Development of Basic Sciences) Geociencias for its financial support, and Graciela Cafferata (ANCAP) for authorizing access to the Queguay quarry. To anonymous reviewers which comments and suggestions helped to improve this paper.

\section{REFERENCES}

ALMEIDA, F.F.M. \& BARBOSA, O. Geologia das quadrículas Piracicaba e Rio Claro, Estado de São Paulo. Boletim da Companhia de Pesquisa de Recursos Minerais, Serviço Geológico do Brasil, v. 143, p. 1-96, 1953.

ALMEIDA, F.F.M.; BRITO-NEVES B.B.; CARNEIRO, C.D.R The origin and evolution of the South American Plataform. Earth-Science Reviews, v. 50, p. 77-111, 2000.

ALONSO-ZARZA, A. Palaeoenvironmental significance of palustrine carbonates and calcretes in the geological record. Earth-Science Reviews, v.60, 261-298, 2003.

ALONSO-ZARZA, A.M.; GNEISE, J.F.; VERDE, M. Sedimentology, diagenesis and ichnology of Cretaceous and Palaeogene calcretes and palustrine carbonates from Uruguay. Sedimentary Geology, v. 236, p. 45-61, 2011.

ALONSO-ZARZA, A.M; MELÉNDEZ, A.; MARTÍNGARCÍA， R.M; HERRERO, J.; MARTÍN-PÉREZ, A. Discriminating between tectonism and climate signatures in palustrine deposits: Lessons from the Miocene of the Teruel Graben, NE Spain. Earth-Science Reviews, v. 113, n. 3/4, p., 141-160, 2012.

ARAKEL, A.V. Evolution of calcrete in palaeodrainages of the Lake Napperby area, Central Australia. Palaeogeography,
Palaeoclimatology, Palaeoecology, v.54, n.1-4, p. 283-303, 1986.

ARAKEL, A.V. \& MCCONCHIE, D. Classification and genesis of ealerete and gypsite lithofacies in paleodrainage systems of inland Australia and their relationship to carnotite mineralization. Journal of Sedimentary Petrology, v. 52, p. $1149-1170,1982$.

BARCELOS, J.H. Reconstrução paleogeográfica da sedimentação do Grupo Bauru baseada na sua redefinição estratigráfica parcial em território paulista e no estudo preliminar fora do estado de São Paulo. Rio Claro, 1984, 191p. Tese (Livre Docência). Instituto de Geociências e Ciências Exatas - Universidade Estadual Paulista.

BARCELOS, J.H. \& SUGUIO, K. Correlação e extensão das unidades litoestratigráficas do Grupo Bauru, definidas em território paulista e nos estados de Minas Gerais, Goiás, Mato Grosso do Sul e Paraná. In: SIMPÓSIO REGIONAL DE GEOLOGIA, 6, 1987, Rio Claro. Atas...Rio Claro: Sociedade Brasileira de Geologia, 1987, v. l, p. 313-321.

BATEZELLI, A. Arcabouço tectono-estratigráfico e evolução das bacias Caiuá e Bauru no Sudeste brasileiro. Revista Brasileira de Geociências, v.40, 265-285, 2010 
BATEZELLI, A. Continental systems tracts of the Brazilian Cretaceous Bauru Basin and their relationship with the tectonic and climatic evolution of South America. Basin Research, v. 27, p. 1-25, 2015.

BOSSI, J. Geología del Uruguay. Departamento de Publicaciones de la Universidad de la República, Montevideo, 469 p., 1966.

BOSSI, J. \& FERRANDO, L. Carta Geológica del Uruguay. Escala 1:500.000. Edición Geoeditores SRL (CD-ROM). Montevideo, 2001.

BOSSI, J.; FERRANDO, L.; FERNÁNDEZ, A.; ELIZALDE, G.; MORALES, H.; LEDESMA, J.; CARBALLO, E.; MEDINA, E.; FORD, I.; MONTAÑA, J. Carta geológica del Uruguay, a escala 1:1.000.000. Dirección de Suelos y Fertilizantes, Montevideo, 1975.

CABRERA, F. Paleobiodiversity and paleoecology of continental mollusks. The Late Cretaceous - Paleogene of Uruguay as a case study. Montevideo, 2015, 90p. Thesis (Master). Programa de Desarrollo de Ciencias Básicas Biología - Universidad de la República.

CABRERA, F. \& MARTÍNEZ, S. Late Cretaceous Pupoides Pfeiffer 1854 (Gastropoda: Pupillidae) from Uruguay (Queguay Formation). Journal of Conchology, v. 42, n. 5, p. 333-338, 2017.

CABRERA, F. \& MARTÍNEZ, S. The oldest Odontostomidae (Mollusca: Gastropoda): Bahiensis priscus n. sp. (Paleocene, Uruguay). Paläontologische zeitschrift, v. 86, p. 451-456, 2012.

CABRERA, F.; MARTÍNEZ, S.; NORBIS, W. Recognition of Biomphalaria species (Gastropoda: Planorbidae) using the spiral growth variability, with description of a new fossil species. Nautilus, v. 130, n. 1, p. 5-12, 2016.

CABRERA, F.; MARTÍNEZ, S.; VERDE M. Continental Late Cretaceous gastropod assemblages from Uruguay Paleoecology age and the oldest record of two families and a genus. Historical Biology, DOI: 10.1080/08912963.2018.1471478, 2018.

CAORSI, J. \& GOÑI, J.C. Geología uruguaya. Boletín del Instituto Geológico del Uruguay, v. 37, p. 1-73, 1958.

CHEBLI, G.; TÓFALO, O.R.; TURAZZINI, G. Mesopotamia. In: CHEBLI, G \& SPALLETTI, L. (Eds.), Cuencas Sedimentarias Argentinas, Tucumán, Serie Correlación Geológica N ${ }^{\circ}$ 6, Instituto Superior de Correlación Geológica, Universidad de Tucumán, p. 79-100, 1989.

DA SILVA, M.L.; BATEZELLI, A.; LADEIRA, F.S. The mineralogy of paleosols in the Marilia Formation and their importance in the environmental evolution of the Maastrichtian of the Bauru Basin in southeastern. Brazilian Journal of Geology, v. 47, n. 3, p. 403-426, 2017.

DAL' BÓ, P.F.F. \& LADEIRA, F.S.B. Ambientes paleoclimáticos da Formação Marília baseado em análise paleopedológica na região de Monte Alto (SP). Geociências, v. 25, 127-134, 2006

DE ALBA, E. \& SERRA, N. Aprovechamiento del Río Uruguay en la zona de Salto Grande. Informe sobre las condiciones y características geológicas. Anales de la Dirección Nacional de Geología v. 11, p. 1-35, 1959.

FEDOROFF, N. \& COURTY M.A. Indicateurs pédologiques d'aridification. In: EXEMPLE DU SAHARA. Bulletin de la Société Géologique de France, Séance spécialisée, Sahara, p. 43-53, 1989.

FERNANDES, L.A. Calcretes e registros de paleossolos em depósitos continentais neocretáceos (Bacia Bauru, Formação Marília). Revista Brasileira de Geociências, v. 40, n. 1, p. 19-35, 2010.

FERNANDES, L.A. \& COIMBRA, A.M. A Bacia Bauru (Cretáceo Superior, Brasil). Anais da Academia Brasileira de Ciências, v. 68, n. 2, p. 195-205, 1996.

FERNANDES, L.A. \& COIMBRA, A.M. Revisão estratigráfica da parte oriental da Bacia Bauru (Neocretáceo). Revista Brasileira de Geociências, v. 30, n.4, p. 717-728, 2000.
FORD, I. Conglomerados con nidos de insectos fósiles: Formación Palmitas (Provisorio) - Terciario inferior (Tentativo). In: PANEL DE GEOLOGÍA DEL LITORAL, 6, REUNIÓN DE GEOLOGÍA DEL URUGUAY, 1988, Salto, Uruguay. Actas... Salto: SUG, p. 47-49, 1988.

FORD, I. \& GANCIO, F. Memoria explicativa y carta geológica del Uruguay, escala 1/100.000 Hoja O - 21 Bizcocho. Facultad de Agronomía, Facultad de Humanidades y Ciencias y Dirección Nacional de Minería y Geología, 1989a.

FORD, I. \& GANCIO, F. Memoria Explicativa y Carta geológica del Uruguay, escala 1/100.000 Hoja O - 22 Palmitas. Facultad de Agronomía, Facultad de Humanidades y Ciencias y Dirección Nacional de Minería y Geología, 1989b.

FRENGUELLI, J. Apuntes de geología uruguaya. Boletín del Instituto de Geología y Perforaciones, v. 11, p. 1- 47, 1930.

FÚLFARO, V.J. Geología del Paraguay Oriental. In: COMINCHIARAMONTI, P. \& GOMES, C.B. (eds.). Magmatismo Alcalino en Paraguay Central - Oriental Relaciones con Magmatismo Coeval en Brasil. Edusp/Fapesp, Sao Paulo, p 11-29, 1996

FÚLFARO, V.J. \& PERINOTTO, J.A.J. A Bacía Bauru: estado da arte. Boletim do Simposio sobre o Cretáceo do Brasil, v. 4, p. 297-303, 1996

FÚLFARO, V.J.; SAAD, R.A.; PERINOTTO, J.A.J.; ETCHEBEHERE, M.L. de C.; VEROSLAVSKY, G. Paraná Basin: Mineral Resources Potential in Brazil, Uruguay and Paraguay, International Geology Review, v. 30, n. 8, p. 703722, 1997.

GALÁN, E. \& POZO, M. Palygorskite and sepiolite deposits in continental environments. Description, genetic patterns and sedimentary settings. In: GALAN, E. \& SINGER, A. (Eds.), Developments in Palygorskite-Sepiolite Research: a New Outlook on These Nanomaterials. Elsevier, Amsterdam, p. 125-176, 2011.

GENISE, J.F. \& BOWN, T.M. Uruguay Roselli 1938 and Rosellichnus, n. ichnogenus: Two ichnogenera for cluster of fossil bee cells: Ichnos, v. 4, p. 199-217, 1996.

GENISE, J.F. \& VERDE M. Corimbatichnus fernandezi: A cluster of fossil bee cells from the late cretaceous-early tertiary of Uruguay. Ichnos, v. 7, p. 115-125, 2000.

GOSO, C.A. Análise Estratigráfica do Grupo Paysandú (Cretáceo) na Bacia do Litoral, Uruguai. Rio Claro, 1999, 184 p. Tese (Doutorado), Instituto de Geociências e Ciências Exatas, Universidade Estadual Paulista.

GOSO, H. \& BOSSI, J. Cenozoico. In: BOSSI, J. (ed.) Geología del Uruguay, Departamento de Publicaciones de la Universidad de la República, Montevideo, p. 259-301, 1966.

GOSO, C.A. \& PEREA, D. El Cretácico post-basáltico de la Cuenca Litoral del Río Uruguay: geología y paleontología. In: VEROSLAVSKY, G.; UBILLA, M.; MARTÍNEZ, S. (eds.), Cuencas sedimentarias de Uruguay: geología, paleontología y recursos minerales - Mesozoico. DIRAC, Facultad de Ciencias, Montevideo, p. 141-169, 2003.

GREVENITZ, $P$. The character and genesis of pedogenic calcrete in southern Australia. University of Wollongong Thesis Collection, University of Wollongong,2006.

HALITIM, A.; ROBERT, M.; PEDRO, G. Etude experimentale de l'epigenie calcaire des silicates en milieu confine caracterisation des conditions de son developpement et des modalites de sa mise enjeu. Sci Géol. Mém. Strasbourg, v. 63-73, 1983.

HEAMAN, L.M. The nature of the subcontinental mantle from $\mathrm{Sr}-\mathrm{Nd}-\mathrm{Pb}$ isotopic studies on kimberlitic perovskite. Earth Planetatry Science Letters, v. 92, p. 323-334, 1989.

HEIZEN, W.; CARRIÓN, R.; MASSA, E.; PENA, S.; STAPFF, M. Mapa Hidrogeológico del Uruguay. Dirección Nacional de Minería y Geología, http://www.dinamige.gub.uy/ch25.htm, 2003. 
HERBST, R. Consideraciones estratigráficas y litológicas sobre la Formación Fray Bentos (Oligoceno inferior-medio) de Argentina y Uruguay. Revista de la Asociación Geológica Argentina, v. 35, p. 308-317, 1980.

HUENE, F. von. Terrestrische Oberkreide in Uruguay. Zentralblatt für Geologie, Mineralogie und Paläontologie, v. Ab. B 4, p. 107-112, 1929.

HUENE, F. von. Nuevos dientes de Saurios del Cretácico del Uruguay. Boletín del Instituto Geológico del Uruguay, v. 21, p. 13-20, 1934.

KLAPPA, C.F. A process-response model for the formation of pedogenic calcretes. In: WILSON, R.C.L. (Ed.), Residual deposits: Surface Related Weathering Processes and Materials. Geological Society, Special Public. Blackwell Scientific Publications, Oxford, p. 211-220, 1983.

LAMBERT, R. Memoria explicativa del mapa geológico de los terrenos sedimentarios y de las rocas efusivas del Departamento de Durazno. Boletín del Instituto Geológico del Uruguay, v. 25, p. 1-37, 1939.

LAMBERT, R. Memoria explicativa de un mapa geológico de reconocimiento del Departamento de Paysandú y los alrededores de Salto. Boletín del Instituto Geológico del Uruguay, v. 27, p. 1-41, 1940.

LEE, S.Y. \& GILKES R.J. Groundwater geochemistry and composition of hardpans in southwestern Australian regolith. Geoderma, v. 126, p. 59-84, 2005.

MANGANELLI, A.; GOSO, C.; GUEREQUIZ, R.; FERNANDEZ TURIEL, J.L.; GARCÍA VALLES, M.; GIMENO PÉREZ C. Groundwater arsenic distribution in South-western Uruguay. Environmental Geology, v.53, p. 827-834, 2007.

MARTÍNEZ, S. \& VEROSLAVSKY, G. Registros continentales no depositacionales del Terciario Temprano. In: VEROSLAVSKY, G.; UBILLA, M.; MARTÍNEZ, S. (eds.), Cuencas sedimentarias de Uruguay: geología, paleontología y recursos minerales - Cenozoico. DIRAC, Facultad de Ciencias, Montevideo, p. 63-82, 2004.

MARTÍNEZ, S.; VEROSLAVSKY, G.; CABRERA, F. Calizas del Queguay. Revista del Museo de Ciencias Naturales de Entre Ríos, v. 1, n. 2, p. 1-10, 2015.

MARTÍNEZ, S.; VEROSLAVSKY, G.; VERDE, M. Paleoecología de los paleosuelos calcáreos fosilíferos ("Calizas del Queguay" Paleoceno) de las regiones sur y litoral oeste del Uruguay. In: $11^{\circ}$ CONGRESO LATINOAMERICANO Y $3^{\text {ER }}$ URUGUAYO DE GEOLOGÍA, Actas... CD-Rom, Punta del Este, T p. 219, 2001.

MEDINA, N.; PAPALEO, C.; MARTRES, R. Palygorskita del yacimiento ANCAP de calizas del Queguay, Paysandú Uruguay. Informe de investigación del Centro de Investigaciones Tecnológicas de ANCAP, 16p, 1978.

MENEGAZZO, M.C.; CATUNEANU, O.; CHANG, H.K. The South American retroarc foreland system: the development of the Bauru Basin in the back-bulge province. Marine and Petroleum Geology, v. 23, p. 131-156, 2016.

MONES, Á. 1980. Nuevos elementos de la paleoherpetofauna del Uruguay (Crocodilia y Dinosauria). In: II CONGRESO ARGENTINO DE PALEONTOLOGÍA Y BIOESTRATIGRAFÍA $Y$ I CONGRESO LATINOAMERICANO DE PALEONTOLOGÍA, Buenos Aires, 1980, Actas..., (AGA), v. 1, p. 265-277, 1980.

MONES, Á. Los vertebrados mesozoicos del Uruguay y sus relaciones con los de áreas vecinas. In: ARROYO CABRALES, J. \& POLACO, O.J. (Eds.), Homenaje al Profesor Ticul Álvarez, Instituto Nacional de Antropología e Historia, Colección Científica, v. 357, p. 205-222, 1997.

MONTAÑNO, J.; GAGLIARDI, S.; VIDAL, H.; MONTAÑO, M.; DA LUCENA, L.R.F. Evaluación de la vulnerabilidad a la contaminación del acuífero Mercedes en el área metropolitana de la ciudad de Paysandú - comparación de los métodos God y Drastic. Revista Latino-Americana de Hidrogeología, v.
4, p. 35-45, 2004

MORRÁS, H.; TÓFALO, O.R.; SÁNCHEZ BETTUCCI, L. Weathering process at the boundary between the Mercedes (Cretaceous) and Asencio (Eocene) formations, Southwestern Uruguay. Geociências, v. 29, n. 4, p. 487-500, 2010.

MORTON, L.S. \& HERBST, R. Gastrópodos del Cretácico (Formación Mercedes) del Uruguay. Ameghiniana, v. 30, p. 445-452, 1993.

NASH, D.J. \& MCLAREN, S.J. Kalahari valley calcretes: their nature, origins and environmental 678 significance. Quaternary International, v.111, 3-22, 2003.

PARODIZ, J.J. The Tertiary non-marine Mollusca of South America. Annals of Carnegie Museum, v.4 0, p. 1-242, 1969.

PAULA E SILVA, F.; KIANG, C.H.; CAETANO-CHANG, M.R. Estratigrafia de subsuperfície do Grupo Bauru (K) no Estado de São Paulo. Revista Brasileira de Geociências, v. 35, n. 1, p. 77-88, 2005.

PAZOS, P. J.; TOFALO, R.; LOUREIRO, J. Procesos sedimentarios indicadores palioclimáticos en la sección inferior de la Formación Playa Hermosa, Cuenca Playa Verde, Piriápolis, Uruguay. In: II CONGRESO URUGUAYO DE GEOLOGÍA, II, Punta del Este, 1998. Atas...Punta del Este, 1998, p. 64-69,

PEREA, D. \& MARTÍNEZ, S. 1985. La fauna fósil (Mollusca, Reptilia y Mammalia) de los Arroyos Gutiérrez Grande y Chico, Departamento de Río Negro, Uruguay. Boletín de la Sociedad Zoológica del Uruguay (2 ${ }^{\mathrm{a}}$ Epoca), v. 2, p. 47-53, 1985.

PEREA, D., SOTO, M., MONTENEGRO, F., CORONA, A. Nuevo hallazgo de restos de titanosaurios (Dinosauria, Sauropoda) en la Formación Mercedes (Cretácico Tardío), Uruguay. Ameghiniana, 44, 42, 2009.

POTTER, P.E. The Mesozoic and Cenozoic paleodrainage of South America: a natural history. Journal of South American Earth Sciences, v. 10, p. 331-344, 1997.

PRECIOZZI, F., SPOTURNO J., HEINZEN W., ROSSI, P. Carta geológica del Uruguay (1:500.000), Dirección Nacional de Minería y Geología (DINAMIGE), Montevideo, p.45, 1985.

RICCARDI, A.C. The Cretaceous System of Southern South America. Memoir of the Geological Society of America, p. 1-168, 1998.

RODAS, M.; LUQUE, F.J.; MAS, R.; GARZON, M.G. Calcretes, palcretes and silcretes in the Paleogene detrital sediments of the Duero and Tajo basins, central Spain. Clays Minerals, v. 29, p. 273-285, 1994.

ROSELLI, F.L. Apuntes de geología y paleontología uruguayas y sobre insectos del Cretáceo del Uruguay o descubrimientos de admirables instintos constructivos de esa época. Boletín de la Sociedad Amigos de las Ciencias Naturales “Kraglievich-Fontana”, v. 1, n. 2, p. 29-102, 1939.

ROSELLI, F.L. Paleoicnología, nidos de insectos fósiles de la cubierta mesozoica del Uruguay. Publicaciones del Museo Municipal de Nueva Palmira, v. 1, n. 1, p. 1-56, 1987.

RUSCONI, C. Sobre reptiles cretáceos del Uruguay (Uruguaysuchus Aznarezi, ng. n.sp.) y sus relaciones con los notosúquidos de Patagonia. Boletín del Instituto de Geología y Perforaciones del Uruguay, v. 19, p. 3-64, 1933.

SANTUCCI, R.M. \& BERTINI, R.J. Distribuição paleogeográfica e biocronológica dos Titanossauros (Saurischia, Sauropoda) do Grupo Bauru, Cretáceo Superior do sudeste brasileiro. Revista Brasileira de Geociências, v. 31, n. 3, p. 307-314, 2001.

SCHOBBENHAUS, C. \& BRITO NEVES, B.B.de. A Geologia do Brasil no Contexto da Plataforma Sul-Americana Geology of Brazil in the Context of the South American Platform. In: BIZZI, L.A.; SCHOBBENHAUS, C.; VIDOTTI, R.M.; GONÇALVES, E.J.H. (eds.), Geologia, Tectônica e Recursos Minerais do Brasil, Companhia de Pesquisa de Recursos Minerais, Serviço Geológico do Brasil CPRM, 
Brasília, p. 5-26, 2003.

SERRA, N. Memoria explicativa del mapa geológico del Departamento de Soriano. Boletín del Instituto Geológico del Uruguay, v. 32, p. 1-42, 1945.

SETZER, J. Algumas contribuições geológicas dos estudos de solos realizados no estado de São Paulo. Revista Brasileira de Geografia, v. 10, n. 1, p. 41-104, 1948.

SOTO, M.; PEREA, D.; CAMBIASO, A. First sauropod (Dinosauria: Saurischia) remains from the Guichón Formation, Late Cretaceous of Uruguay. Journal of South American Earth Sciences, v. 33, p. 68-79, 2011a.

SOTO, M.; POL, D.; PEREA, D. 2011b. A new specimen of Uruguaysuchus aznarezi (Crocodyliformes: Notosuchia) from the middle Cretaceous of Uruguay and its phylogenetic relationships. Zoological Journal of the Linnean Society, v. 163, p. 173-198, 2011b.

SPRECHMANN, P.; BOSSI, J.; DA SILVA, J. Cuencas del Jurásico y Cretácico del Uruguay. In: W. VOLKHEIMER, W. \& MUSSACHIO, E.A. (Eds.), Cuencas sedimentarias del Jurásico y Cretácico de América del Sur, Comité sudamericano del Jurásico y Cretácico, Buenos Aires, p. 239270, 1981.

SUGUIO, K. \& BARCELOS, J.H. Calcretes of the Bauru Group (Cretaceous), Brazil: petrology and geological significance. Boletim do Instituto de Geociências (USP), v.14, 31-47, 1983.

TANDON, S. \& ANDREWS, J. Lithofacies associations and stable isotopes of palustrine and calcrete carbonates: examples from Indian Maastrichtian regolith. Sedimentology, v. 48, p. 339-355, 2001.

TÓFALO, O.R. Depósitos clásticos y carbonáticos del Cretácico Superior, Formación Puerto Yeruá, Entre Ríos. In: $1^{\mathrm{RA}}$ REUNIÓN ARGENTINA DE SEDIMENTOLOGÍA, 1986, La Plata, Actas..., La Plata, v. 1, p. 201-204,1986.

TÓFALO, O.R. \& PAZOS, P. Caracterización de calcretes de la Formación Puerto Yeruá (Cretácico), en base a su micromorfología (Entre Ríos, Argentina). Revista de la Asociación Argentina de Sedimentología, v. 9, n. 2, p. 127 13, 2002.

TÓFALO, O.R. \& MORRÁS, H.J.M. Evidencias Paleoclimáticas en duricostras, paleosuelos y sedimentitas silicoclásticas del Cenozoico de Uruguay. Revista de la Asociación Geológica Argentina, v. 65, n. 4, p. 674-686, 2009.

TÓFALO, O.R. \& PAZOS, P.J. Paleoclimatic implications (Late Cretaceous-Paleogene) from micromorphology of calcretes, palustrine limestones and silcretes, southern Paraná Basin, Uruguay. Journal of South American Earth Sciences, v. 29, p. 665-675, 2010.

TÓFALO, O. R.; PAZOS, P. J.; SÁNCHEZ BETTUCCI, L.; DE SANTA ANA, H.; ALONSO, S. Caracterización micromorfológica de calcretes, "Calizas del Queguay",
Departamento Paysandú, Uruguay. In: $11^{\circ}$ CONGRESO LATINOAMERICANO Y $3^{\mathrm{ER}}$ URUGUAYO DE GEOLOGÍA, Actas... CD-Rom, Punta del Este, p. 5-24, 2001.

VERDE, M. Icnología de la Formación Asencio y las “Calizas del Queguay”. Montevideo, 204p., 2012. Tesis (Doctorado). Programa de Desarrollo de Ciencias Básicas - Universidad de la República.

VEROSLAVSKY, G. \& MARTÍNEZ, S. Registros no depositacionales del Paleoceno - Eoceno del Uruguay: Nuevo enfoque para viejos problemas. Revista Universidade Guarulhos, Série Geociências, v. 1, n. 3, p. 32-41, 1996.

VEROSLAVSKY, G.; DE SANTA ANA, H.; GOSO, C.; GONZÁLEZ, S. Calcretas y silcretas de la región Oeste del Uruguay (Queguay), Cuenca de Paraná (Cretácico Superior Terciario Inferior). Geociências, v. 16, p. 205-224, 1997.

VEROSLAVSKY, G. \& DE SANTA ANA, H. Calizas del Queguay: génesis y potencial económico. In: VEROSLAVSKY, G.; UBILLA, M.; MARTÍNEZ, S. (eds.), Cuencas sedimentarias de Uruguay: geología, paleontología y recursos minerales - Cenozoico. DIRAC, Facultad de Ciencias, Montevideo, p. 269-296, 2004.

WALTHER, K. Líneas fundamentales de la Estructura Geológica de la República Oriental del Uruguay. Boletín del Instituto Nacional de Agronomía, v. 1, p. 1-186, 1919

WALTHER, K. Sedimentos gelíticos y clastogelíticos del Cretácico superior y Terciario uruguayos. Boletín del Instituto Geológico del Uruguay, v. 13, p. 1-94, 1930.

WALTHER, K. La visita de Charles Darwin en 1833 al Cerro de los Claveles sobre el Arroyo Perico Flaco, afluente del Río Negro (Departamento de Soriano). Revista de la Facultad de Agronomía, v.8, p. 1-15, 1933.

WRIGHT, V.P. A micromorphological classification of fossil and recent calcic and petrocalcic microstructures. In: DOUGLAS, L. (Ed.), Soil Micromorphology: A Basic and Applied Science. Development in Soil Science, v. 19, p. 401-407, 1990.

WRIGH, V.P. \& TUCKER, M.E. Calcretes: an introduction. In: WRIGHT, V.P. \& TUCKER, M.E. (Eds.) Calcretes. International Association of Sedimentologists, Blackwell Scientific Publications, Oxford (Reprint Series), p. 1-22, 1991. 